\title{
Interventions for isolated diaphyseal fractures of the ulna in adults (Review)
}

\author{
Handoll HHG, Pearce P
}

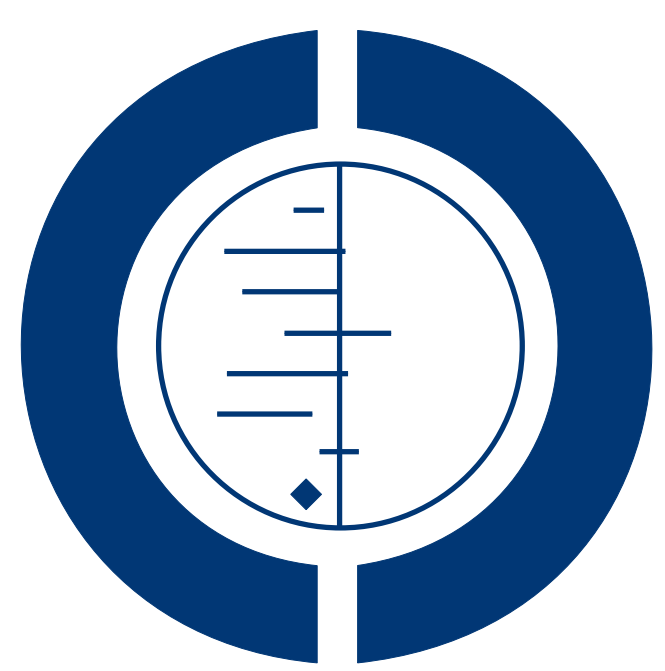

\section{THE COCHRANE COLLABORATION $^{\circledR}$}

This is a reprint of a Cochrane review, prepared and maintained by The Cochrane Collaboration and published in The Cochrane Library 2009, Issue 3

http://www.thecochranelibrary.com

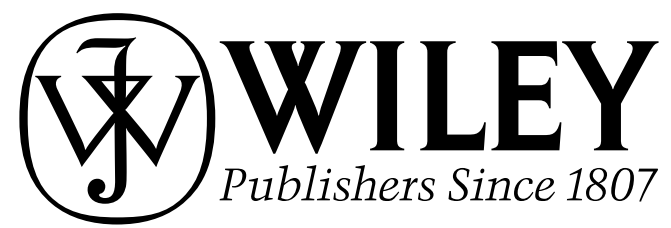

Interventions for isolated diaphyseal fractures of the ulna in adults (Review)

Copyright $\odot 2009$ The Cochrane Collaboration. Published by John Wiley \& Sons, Ltd. 
TABLE OF CONTENTS

HEADER . . . . . . . . . . . . . . . . . . . . . . . . . . . . . . . . . . . . . . . 1

ABSTRACT . . . . . . . . . . . . . . . . . . . . . . . . . . . . . . . . . . . . . . . . . . . . . . 1

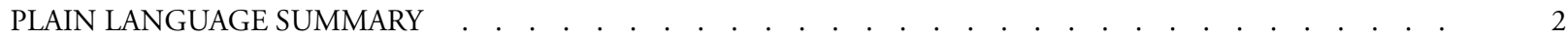

BACKGROUND . . . . . . . . . . . . . . . . . . . . . . . . . . . . . . . . . . . . 2

OBJECTIVES . . . . . . . . . . . . . . . . . . . . . . . . . . . . . . . . . . . . . 3

METHODS . . . . . . . . . . . . . . . . . . . . . . . . . . . . . . . . . . . . . . 3

RESULTS . . . . . . . . . . . . . . . . . . . . . . . . . . . . . . . . . . . . 7

Figure 1. . . . . . . . . . . . . . . . . . . . . . . . . . . . . . . . . . . . . . 10

DISCUSSION . . . . . . . . . . . . . . . . . . . . . . . . . . . . . . . . . . 14

AUTHORS' CONCLUSIONS . . . . . . . . . . . . . . . . . . . . . . . . . . . . . . . . . . . . . . 15

ACKNOWLEDGEMENTS . . . . . . . . . . . . . . . . . . . . . . . . . . . . . . . . . . . . . . . . . .

REFERENCES . . . . . . . . . . . . . . . . . . . . . . . . . . . . . . . . . . . . . . 16

CHARACTERISTICS OF STUDIES . . . . . . . . . . . . . . . . . . . . . . . . . . . . . . . 17

DATA AND ANALYSES . . . . . . . . . . . . . . . . . . . . . . . . . . . . . . . . . . . . . . . . . . . . . . 26

Analysis 1.1. Comparison 1 Immediate mobilisation versus plaster cast immobilisation, Outcome 1 Delayed union (at 12 weeks). . . . . . . . . . . . . . . . . . . . . . . . . . . . . 27

Analysis 2.1. Comparison 2 Short arm plaster cast versus long arm plaster cast immobilisation, Outcome 1 Delayed union (at 12 weeks). . . . . . . . . . . . . . . . . . . . . . . . . . . . . . . . . . . . 27

Analysis 3.1. Comparison 3 Point contact fixator (PC-Fix) versus the limited contact dynamic compression plate (LCDCP), Outcome 1 Anatomical outcomes. . . . . . . . . . . . . . . . . . . . . . . . . 28

Analysis 3.2. Comparison 3 Point contact fixator (PC-Fix) versus the limited contact dynamic compression plate (LCDCP), Outcome 2 Functional outcomes. . . . . . . . . . . . . . . . . . . . . . . . . 28

Analysis 3.3. Comparison 3 Point contact fixator (PC-Fix) versus the limited contact dynamic compression plate (LCDCP), Outcome 3 Complications. . . . . . . . . . . . . . . . . . . . . . . . . . . 29

APPENDICES . . . . . . . . . . . . . . . . . . . . . . . . . . . . . . . . . . . . . 29

WHAT'S NEW . . . . . . . . . . . . . . . . . . . . . . . . . . . . . . . . . . . . . 31

HISTORY . . . . . . . . . . . . . . . . . . . . . . . . . . . . . 31

CONTRIBUTIONS OF AUTHORS . . . . . . . . . . . . . . . . . . . . . . . . . . . . . . 31

DECLARATIONS OF INTEREST . . . . . . . . . . . . . . . . . . . . . . . . . . . . . . . . . . . . . . . 32

SOURCES OF SUPPORT . . . . . . . . . . . . . . . . . . . . . . . . . . . . . . . . . . . . . . .

NOTES . . . . . . . . . . . . . . . . . . . . . . . . . . . . . . . . . . . . 32

INDEX TERMS . . . . . . . . . . . . . . . . . . . . . . . . . . . . . . . . . . . . 33

Interventions for isolated diaphyseal fractures of the ulna in adults (Review)

Copyright ( 2009 The Cochrane Collaboration. Published by John Wiley \& Sons, Ltd. 


\title{
[Intervention Review]
}

\section{Interventions for isolated diaphyseal fractures of the ulna in adults}

\author{
Helen HG Handoll ${ }^{2}$, Paddy Pearce ${ }^{1}$ \\ ${ }^{1}$ NHS North Yorkshire and York, Thirsk, UK. ${ }^{2}$ Centre for Rehabilitation Sciences (CRS), Research Institute for Health Sciences and \\ Social Care, University of Teesside, Middlesborough, UK \\ Contact address: Paddy Pearce, NHS North Yorkshire and York, Station Road Business Park, Station Road, Thirsk, North Yorkshire, \\ YO7 1PZ, UK. Paddy.Pearce@nyypct.nhs.uk.
}

Editorial group: Cochrane Bone, Joint and Muscle Trauma Group.

Publication status and date: New search for studies and content updated (conclusions changed), published in Issue 3, 2009.

Review content assessed as up-to-date: 25 January 2009.

Citation: Handoll HHG, Pearce P. Interventions for isolated diaphyseal fractures of the ulna in adults. Cochrane Database of Systematic Reviews 2009, Issue 3. Art. No.: CD000523. DOI: 10.1002/14651858.CD000523.pub3.

Copyright (C) 2009 The Cochrane Collaboration. Published by John Wiley \& Sons, Ltd.

\section{A B S T R A C T}

\section{Background}

Isolated fractures of the shaft of the ulna, which are often sustained when the forearm is raised to shield against a blow, are generally treated on an outpatient basis.

\section{Objectives}

To assess the effects of various forms of treatment for isolated fractures of the ulnar shaft in adults.

\section{Search strategy}

We searched the Cochrane Bone, Joint and Muscle Trauma Group Specialised Register (December 2008), the Cochrane Central Register of Controlled Trials (The Cochrane Library 2008, Issue 4), MEDLINE (1966 to November week 3 2008), EMBASE (1981 to week 52 2008), CINAHL (1982 to December week 2 2008), various trial registers, various conference proceedings and bibliographies of relevant articles.

\section{Selection criteria}

Randomised or quasi-randomised trials of conservative and surgical treatment of isolated fractures of the ulnar shaft in adults. Excluded were fractures of the proximal ulna and Monteggia fracture dislocations.

\section{Data collection and analysis}

We performed independent assessment of risk of bias and data extraction. We contacted trialists for more information. There was no pooling of data.

\section{Main results}

Four trials, involving a total of 237 participants, were included. All four trials were methodologically flawed and potentially biased.

Three trials tested conservative treatment interventions. One trial, which compared short arm (below elbow) pre-fabricated functional braces with long arm (elbow included) plaster casts, found there was no significant difference in the time it took for fracture union. Patient satisfaction and return to work during treatment were significantly better in the brace group. The other two trials, both quasi- 
randomised, had three treatment groups. One trial compared Ace Wrap elastic bandage versus short arm plaster cast versus long arm plaster cast. The large loss to follow-up in this trial makes any data analysis tentative. However, the need for replacement of the Ace wrap by other methods due to pain indicates the potential for a serious problem with this intervention. The other trial, which compared immediate mobilisation versus short arm plaster cast versus long arm plaster cast for minimally displaced fractures, found no significant differences in outcome between these three interventions.

The fourth trial, which compared two types of plates for surgical fixation, found no significant differences in functional or anatomical outcomes nor complications between the two groups.

\section{Authors' conclusions}

There is insufficient evidence from randomised trials to determine which method of treatment is the most appropriate for isolated fractures of the ulnar shaft in adults. Well designed and reported randomised trials of current forms of conservative treatment are recommended.

\section{PLAIN LANGUAGE SUMMARY}

\section{Interventions for treating adults with an isolated fracture of the ulnar shaft}

The ulna is one of the two bones of the forearm. Isolated fractures of the shaft of the ulna, without other fractures, often result when the forearm is raised to fend off a blow. Such fractures are fairly rare, but can result in significant disability. Most people are treated in outpatients with plaster casts or arm braces. Some are treated surgically. Surgery generally involves the re-alignment and fixation of the broken ends of the bone.

Four trials, involving a total of 237 participants, were included in the review. These trials had methodological weaknesses that could have resulted in serious bias. One trial compared 'short arm' (splintage stopping below the elbow) pre-fabricated functional braces with 'long arm' (splintage includes the elbow) plaster casts. It found no clear difference between the two groups in the time taken for the fracture to heal. However, significantly more people in the brace group were satisfied with their treatment and significantly more returned to work during their treatment. One trial compared Ace Wrap elastic bandage, short arm plaster cast and long arm plaster cast. The large loss to follow-up in this trial makes any findings tentative. However, the need for replacement of the Ace wrap by other methods due to pain does indicate the potential for a serious problem with this intervention. The third trial, which compared immediate mobilisation versus short arm plaster cast versus long arm plaster cast for minimally displaced fractures, found no clear differences in outcome between these three interventions. The fourth trial found no significant differences in functional or anatomical outcomes nor complications between the two types of plates used for surgical fixation of the fracture.

Overall, there was not enough evidence from randomised controlled trials to show which methods of treatment are better for these injuries.

\section{B A C K G R O U N D}

\section{Description of the condition}

Isolated fractures of the shaft of the ulna are often sustained when the forearm is raised to shield against a blow. The energy is then absorbed by the subcutaneous ulna resulting in the characteristic 'nightstick' type fracture (Atkin 1995a). (A nightstick is an American policeman's truncheon.) This type of fracture frequently occurs in young males involved in violent activities (Du Toit 1979). Epidemiological data on the incidence of this injury is difficult to locate, probably as most of these fractures are treated on an outpatient basis. Initially in the absence of accessible general information, one of us (Pearce) examined his local hospital database at the time and found that the Friarage Hospital, Northallerton, a small District General Hospital in rural Northern England which serves a population of 122,000 , had a total of 26 cases of isolated fracture of the ulna in 1997. Most of these injuries were a result of direct violent or high energy impact and many involved incidents with cattle or horses. This figure gives a local incidence rate of 0.2 per 1000 population. This agrees with the general impression of low incidence but it is not known how this figure compares nationally or internationally. Subsequently, we located a report of an 
epidemiological study of people over 14 years of age with fractures of the radius and ulna presenting to the Orthopaedic Trauma Unit of the Royal Infirmary of Edinburgh, UK, over a three year period starting January 1990 (McQueen 2000). This unit, which serves a population of around 650,000 meeting the above age criterion, treated a total of 72 cases of isolated fractures of the ulna over the three year period. This gives an annual incidence of approximately 0.04 per 1,000 population, which is a fifth of the rate in Northallerton. Nonetheless, we still anticipate that the incidence is likely to be higher in bigger cities and other areas where violence is more common. McQueen 2000 reported that 38\% of the injuries resulted from a direct blow, 31\% from a simple fall and 14\% from pedestrian road traffic accidents; the mechanism of injury was not stated for the other $17 \%$ but none involved sport. Nearly two thirds of the study population was male (63\%). The mean age of patients was 43 years; range 18 to 94 years. There was a bimodal distribution of annual age and sex specific incidence; the incidence in males was highest in the youngest age group and tapered off with age, whereas that in females increased gradually for the first few decades and then, reflecting underlying osteoporosis, more dramatically in the elderly.

Although not common, the fracture appears to have a high complication rate, principally non-union, malunion, reduction in the range of wrist and elbow movements, pain and deformity. For instance, Grace 1980 reported a fracture non-union rate of $14 \%$. In a brief review of the results of seven studies of people treated for ulna fracture, Pollock 1983 reported non-union rates ranging from 1 to $12 \%$, impairment of forearm rotation between 18 to $32 \%$ of patients and, for four studies, significant reductions in elbow flexion and extension. A similar picture is conveyed in a more recently published review of 33 "series" by Mackay 2000 . Such complications may have an effect upon a person's ability to perform their activities of daily living and can prevent them from returning to their previous employment (Atkin 1995a).

\section{Description of the intervention}

The most suitable method of management of this injury has not been established. The choice of treatment will be influenced by the mechanism of injury, fracture pattern, degree of displacement, angulation and location, associated injuries, as well as patient preferences. The treatment options are:

(1) Conservative treatment with:

(a) above elbow plaster cast;

(b) below elbow plaster cast;

(c) functional brace;

(d) Ace wrap elastic bandage (Pollock 1983);

(e) sling (De Jong 1989).

(2) Open reduction and internal fixation with:

(a) plates;

(b) intramedullary nails/devices.
The evaluation of treatment has been traditionally based on either anatomical accuracy of reduction and/or functional outcomes based on range of movement, pain, grip strength, residual soft tissue swelling, local complications, cosmetic appearance, patient satisfaction with treatment, and activities of daily living.

\section{Why it is important to do this review}

Though isolated ulnar shaft fractures are comparatively rare, there remains a need to establish the best methods to manage these fractures which are often associated with a high rate of complications and, for some, serious limitations in function. This update continues the review of evidence for treatment interventions as it accrues, albeit slowly.

\section{O B J E C T IVES}

We aimed to determine, based on evidence from randomised controlled trials, the most appropriate treatment for isolated fractures of the ulnar shaft in adults.

We aimed to compare the relative effects (benefits and harms) of the following for adults with displaced or non-displaced isolated fractures of the ulnar shaft.

- Any method of conservative treatment versus any other method of conservative treatment.

- Any method of surgical treatment versus any method of conservative treatment.

- Any method of surgical treatment versus any other method of surgical treatment.

\section{MET HO D S}

\section{Criteria for considering studies for this review}

\section{Types of studies}

Any randomised or quasi-randomised (methods of allocating participants to a treatment which are not strictly random e.g. by date of birth, hospital record number, alternation) clinical trials of interventions listed below were considered. 


\section{Types of participants}

Adults of either gender with an isolated fracture of the mid and lower third of the ulna above the distal radio-ulnar joint. Studies which focus solely on ulnar shaft fractures in children or Monteggia fractures were to be excluded.

\section{Types of interventions}

Conservative treatment using above or below elbow plaster casts or functional braces, or surgical treatment involving open reduction and internal fixation.

\section{Types of outcome measures}

Data for the following outcomes were sought.

\section{Primary outcomes}

(1) Subjective functional outcomes, preferable validated self-reported assessment of upper-limb function and activities of daily living, such as Disabilities of the Arm, Shoulder and Hand (DASH: Beaton 2001), or overall function, e.g. Short Musculoskeletal Function Assessment (SMFA: Swiontkowski 1999), and SF-36 physical component scale.

(2) Non or delayed union, preferably confirmed radiologically.

\section{Secondary outcomes}

(3) Health related quality of life outcomes, e.g. SF-36

(4) Patient satisfaction with outcome

(5) Pain

(6) Clinical outcomes: residual soft tissue swelling, local and other complications, cosmetic appearance, non or delayed union, time to recover.

(7) Range of movement

(8) Radiographic results: non-union and deformity

\section{Economic outcomes}

Surgical intervention, hospital stay, physiotherapy, return to work and time off work.

\section{Search methods for identification of studies}

\section{Electronic searches}

We searched the Cochrane Bone, Joint and Muscle Trauma Group Specialised Register (December 2008), the Cochrane Central Register of Controlled Trials (The Cochrane Library 2008, Issue 4), MEDLINE (1966 to November week 3 2008), EMBASE (1981 to week 52 2008) and the Cumulative Index to Nursing and Allied
Health Literature -CINAHL (1982 to December week 2 2008). We also searched Current Controlled Trials (accessed November 2008), the UK National Research Register archives (covers up to September 2007), and the WHO International Clinical Trials Registry Platform (accessed November 2008) for ongoing and recently completed trials.

The subject specific terms used for MEDLINE (OVID WEB) and CINAHL (OVID WEB) are shown in Appendix 1. In MEDLINE, the search strategy was combined with the first two sections of optimal MEDLINE search strategy for randomised trials ( Higgins 2006). The search strategies for EMBASE (OVID WEB), CINAHL (OVID WEB) and The Cochrane Library (Wiley InterScience) are also shown in Appendix 1.

\section{Searching other resources}

We handsearched the British Volume of the Journal of Bone and Joint Surgery supplements (1996 to 2006), abstracts of the American Society for Surgery of the Hand annual meetings (2000 to 2007) and abstracts of the American Orthopaedic Trauma Association annual meetings (up to 2008). Previously, we searched the following conference proceedings on the Acta Orthopaedica Scandinavica web page: Danish Orthopedic Society, Arhus, May 2001; Danish Orthopedic Society, Copenhagen, October 2000; Danish Orthopedic Society, Odense, May 2000; Netherlands Orthopedic Society, Groningen, May 2001; Netherlands Orthopaedic Association, Utrecht, September 2000; Netherlands Orthopaedic Association, Rotterdam, January 2000; Nordic Orthopaedic Federation, Tampere, Finland, June 2000; Norwegian Orthopedic Society, Oslo, October 1999; Swedish Orthopaedic Association, Vaxjo, September 2000.

We scrutinised weekly downloads of "Fracture" articles in new issues of 17 journals (Acta Orthop Scand; Am J Orthop; Arch Orthop Trauma Surg; Clin J Sport Med; Clin Orthop; Emerg Med Clin North Am; Foot Ankle Int; Injury; J Accid Emerg Med; J Am Acad Orthop Surg; J Arthroplasty; J Bone Joint Surg Am; J Bone Joint Surg Br; J Foot Ankle Surg; J Orthop Trauma; J Trauma; Orthopedics) from AMEDEO.

We checked reference lists of all identified articles and reviews.

No language restriction was applied.

The search concluded in December 2008.

\section{Data collection and analysis}

\section{Selection of studies}

All identified trials were independently assessed for inclusion by both review authors using the above criteria. 


\section{Data extraction and management}

Data were independently extracted by both review authors using a pre-derived data extraction form and entered into RevMan. Trialists were contacted for further details of their trials.

\section{Assessment of risk of bias in included studies}

Methodological quality and risk of bias was independently assessed, without masking of the source and authorship of the trial reports, by both review authors. Any disagreement was resolved by discussion. For this update, we continued to use our subjectspecific modification of the former generic evaluation tool developed by the Cochrane Bone, Joint and Muscle Trauma Group. We modified this by replacing the scores 2, 1, 0 respectively by $\mathrm{Y}$ (yes, criterion satisfied), ? (unclear or criterion partially satisfied), and $\mathrm{N}$ (no, criterion not satisfied). Table 1 shows the grading scheme based on 11 aspects of trial validity, plus brief notes of coding guidelines including the specific scores for items 9,10 and 11 for the outcome of fracture non-union. Additionally, we independently assessed risk of bias using the tool outlined in the Cochrane Handbook for Systematic Reviews of Interventions ( Higgins 2008). This tool incorporates assessment of randomisation (sequence generation and allocation concealment), blinding (of participants, treatment providers and outcome assessors), completeness of outcome data, selection of outcomes reported and other sources of bias. We considered patient-rated and clinicianrated outcomes separately in our assessment of blinding and completeness of outcome data. We assessed two additional sources of bias: selection bias resulting from imbalances in key baseline characteristics (age, sex, fracture location, pattern and displacement, and associated soft tissue); and performance bias resulting from lack of comparability in the experience of care providers and provision of treatment interventions such as advice on activity, exercises undertaken, timing of intervention.

Table 1. Methodological quality assessment scheme

\begin{tabular}{|c|c|c|}
\hline Items & Grades & Notes \\
\hline $\begin{array}{l}\text { 1. Was the assigned treatment adequately } \\
\text { concealed prior to allocation? }\end{array}$ & $\begin{array}{l}\mathrm{Y}=\text { method did not allow disclosure of as- } \\
\text { signment. } \\
? \text { = small but possible chance of disclosure } \\
\text { of assignment or unclear. } \\
\mathrm{N} \text { = quasi-randomised or open list/tables. }\end{array}$ & $\begin{array}{l}\text { Cochrane code: Clearly yes = A; Not sure } \\
=\text { B; Clearly no }=\text { C }\end{array}$ \\
\hline $\begin{array}{l}\text { 2. Were the outcomes of participants who } \\
\text { withdrew described and included in the } \\
\text { analysis (intention to treat)? }\end{array}$ & $\begin{array}{l}\mathrm{Y}=\text { withdrawals well described and ac- } \\
\text { counted for in analysis. } \\
?=\text { withdrawals described and analysis not } \\
\text { possible. } \\
\mathrm{N}=\text { no mention, inadequate mention, or } \\
\text { obvious differences and no adjustment. }\end{array}$ & \\
\hline
\end{tabular}


3. Were the outcome assessors blinded to $\mathrm{Y}=$ effective action taken to blind assessors. treatment status?

$?=$ small or moderate chance of unblinding

of assessors.

$\mathrm{N}=$ not mentioned or not possible.

4. Were the treatment and control group $\mathrm{Y}=$ good comparability of groups. comparable at entry?
$?=$ confounding small; mentioned.

$\mathrm{N}=$ large potential for confounding, or not discussed.
The principle confounders were considered to be: age, sex, fracture location, pattern and displacement, and associated soft tissue injury.
5. Were the participants blind to assignment status after allocation?
$\mathrm{Y}=$ effective action taken to blind participants.

$?=$ small or moderate chance of unblinding of participants.

$\mathrm{N}=$ not possible, or not mentioned (unless double-blind), or possible but not done.
6. Were the treatment providers blind to assignment status?
$\mathrm{Y}=$ effective action taken to blind treatment providers.

$?=$ small or moderate chance of unblinding of treatment providers.

$\mathrm{N}=$ not possible, or not mentioned (unless double-blind), or possible but not done.
7. Were care programmes, other than the $Y=$ care programmes clearly identical. trial options, identical? clear but trivial differences.
Examples of clinically important differences in other interventions which could $\mathrm{N}=$ not mentioned or clear and important differences in care programmes. act as active measures for treatment of ulna fractures were considered to be: advice on activity, exercises undertaken, timing of intervention etc.

\section{Were the inclusion and exclusion criteria $\mathrm{Y}=$ clearly defined. clearly defined? \\ ? = inadequately defined. \\ $\mathrm{N}=$ not defined.}

9. Were the outcome measures used clearly $\mathrm{Y}=$ clearly defined. $\mathrm{N}=$ not defined.

10. Were diagnostic tests used in outcome $\mathrm{Y}=$ optimal. assessment clinically useful? (by outcome) $\mathrm{N}=$ adequate.

? = not defined, not adequate. defined? (by outcome measure) ? = inadequately defined.

For fracture non-union: Was the algorithm for detection clearly described?

For fracture union (non-union): 2 = full bridging of external callus determined radiographically, and no pain on forearm movement.

$1=$ as above but no associated test for pain. $0=$ no mention of criteria.

11. Was the duration of surveillance clini- $Y=$ optimal. cally appropriate?(by outcome measure) $\quad ?=$ adequate. $\mathrm{N}=$ not defined, not adequate.
For fracture union (non-union):

$2=26$ weeks or more post injury. $1=10-26$ weeks. 


\section{Data synthesis}

Where available, discrete outcome data were tested for statistical significance using risk ratios and $95 \%$ confidence intervals. No data pooling was appropriate and no sensitivity or subgroup analyses were undertaken.

\section{R E S U L T S}

\section{Description of studies}

See: Characteristics of included studies; Characteristics of excluded studies.

\section{Results of the search}

The updating of the search from September 2006 to December 2008 resulted in the identification of one new trial (Van Leemput 2007).

Table 2 is a compilation of our reports of the products of the search strategies and study selection decisions from the previous eight versions of the review.

Table 2. History of search results and study selection decisions

\begin{tabular}{|c|c|c|}
\hline Version & Date searched up to & Report \\
\hline $\begin{array}{l}\text { 1st version } \\
\text { Issue } 3,1998\end{array}$ & July 1997 & $\begin{array}{l}\text { "The specific MEDLINE search, run from } 1976 \text { to } 1997 \text {, in conjunction with } \\
\text { the first two levels of the optimal RCT specific search (see 'Search strategy for } \\
\text { identification of studies') produced } 32 \text { reports of which } 13 \text { focused on the man- } \\
\text { agement of isolated ulnar fractures, and only two of which were controlled stud- } \\
\text { ies and put forward for inclusion. The EMBASE search run from } 1981 \text { to } 1997 \\
\text { produced } 26 \text { studies, of which seven focused on the management of isolated } \\
\text { fractures of the ulna, but as none of these were controlled, none were put forward } \\
\text { for inclusion. A further two comparative studies (Labbe 1996; Skinner 1989), } \\
\text { both published as abstracts, were identified but were excluded since they were } \\
\text { not randomised or quasi-randomised trials (see the 'Characteristics of excluded } \\
\text { studies'). In their recent response stating that Labbe } 1996 \text { was a retrospective } \\
\text { study, the trialists added that they were working on an randomised controlled } \\
\text { trial investigating the same comparison (percutaneous intramedullary nailing } \\
\text { versus plate fixation). A request for further details of this trial will be sent." }\end{array}$ \\
\hline $\begin{array}{l}\text { 2nd version } \\
\text { Issue } 2,2000\end{array}$ & August 1999 & $\begin{array}{l}\text { "There was no response from Dr Labbe to our request sent September } 1998 \\
\text { for further details on the randomised controlled trial which he mentioned in } \\
\text { his first response. Neither were there details given in the full report of Labbe }\end{array}$ \\
\hline
\end{tabular}


Table 2. History of search results and study selection decisions (Continued)

\begin{tabular}{|c|c|c|}
\hline & & $\begin{array}{l}1996 \text { published in } 1998 \text { (see Footnote). Correspondence in October } 1998 \text { with } \\
\text { Dr Lisa Wood, then an orthopaedic registrar based in the Princess Margaret } \\
\text { Hospital, Swindon, UK, alerted one of the review authors, Helen Handoll, to } \\
\text { the possibility that a comparative study by Goel et al (Goel 1991) could be a } \\
\text { randomised trial. However, since there was no response from the trialists to our } \\
\text { inquiries, we have placed this study in the excluded studies category." }\end{array}$ \\
\hline $\begin{array}{l}\text { 3rd version } \\
\text { Issue } 2,2001\end{array}$ & December 2000 & $\begin{array}{l}\text { "The newly identified trial (Collinge 2000), located via handsearching, involved } \\
\text { a randomised comparison of open reduction and plating with intramedullary } \\
\text { nailing in } 36 \text { patients with } 37 \text { diaphyseal forearm fractures. Separate data were } \\
\text { not presented for the six patients (three in each group) with only an ulnar } \\
\text { fracture. Some of these may have been among the } 10 \text { patients who were not } \\
\text { included in the results. We considered that the sample size was too small to } \\
\text { pursue the data for these patients and thus have excluded this trial." }\end{array}$ \\
\hline $\begin{array}{l}\text { 4th version } \\
\text { Issue } 2,2002\end{array}$ & November 2001 & $\begin{array}{l}\text { "The updating of the search strategy to November } 2001 \text { resulted in the identi- } \\
\text { fication of no new studies." }\end{array}$ \\
\hline $\begin{array}{l}\text { 5th version } \\
\text { Issue } 2,2003\end{array}$ & November 2002 & $\begin{array}{l}\text { "The updating of the search strategy from November } 2001 \text { to November } 2002 \\
\text { resulted in the identification of three new studies. Two of these, published in } \\
\text { German, were located via CENTRAL and the other via MEDLINE. Upon } \\
\text { obtaining translation or through enquiry with the trial investigator, all three } \\
\text { were excluded for reasons given in the 'Characteristics of excluded studies' table." }\end{array}$ \\
\hline $\begin{array}{l}\text { Gth version } \\
\text { Issue } 2,2004\end{array}$ & December 2003 & $\begin{array}{l}\text { "The updating of the search strategy from November } 2002 \text { to December } 2003 \\
\text { resulted in the identification of one new study, which compared two types of } \\
\text { plates used for the surgical fixation of forearm diaphyseal (shaft) fractures ( } \\
\text { Leung 2003). This study was included upon obtaining separate data for patients } \\
\text { with isolated ulnar fractures." }\end{array}$ \\
\hline $\begin{array}{l}7 \text { th version } \\
\text { Issue } 2,2005\end{array}$ & January 2005 & $\begin{array}{l}\text { "The updating of the search strategy from December } 2003 \text { to January } 2005 \\
\text { resulted in the identification of a letter and reply (Rajasekhar 2004) regarding } \\
\text { one of the included trials (Leung 2003). We found no new studies." }\end{array}$ \\
\hline $\begin{array}{l}\text { 8th version } \\
\text { Issue } 1,2007\end{array}$ & September 2006 & $\begin{array}{l}\text { "The updating of the search from January } 2005 \text { to September } 2006 \text { resulted in } \\
\text { the identification of no new studies." }\end{array}$ \\
\hline
\end{tabular}

Labbe JL, Peres O, Leclair O, Goulon R, Bertrou V, Saintlanne S. La fracture isolee de la diaphyse ulnaire, de l'osteosynthese par plaque a l'embrochage centro-medullaire [Fixation of isolated ulnar shaft fracture by open reduction and internal fixation with plate or percutaneous intramedullary nailing]. Revue de Chirurgie Orthopedique et Reparatrice de l'Appareil Moteur 1998;84(6):515-22. 


\section{Included studies}

Four trials (Atkin 1995; Gebuhr 1992; Leung 2003; Van Leemput 2007), involving a total of 237 participants, are included in this review. The majority of the participants were male in two trials ( Atkin 1995: 71\%; Leung 2003: 90\%), but not in Gebuhr 1992 (49\%) or Van Leemput 2007 (42\%). The potential bimodal distribution of age for these fractures has been described in the 'Background' and the age range of the pooled population for this review is 12 to 85 years of age. It is very unlikely that there were more than a very few children in the two trials (Gebuhr 1992; Leung 2003), but there were no data to confirm this.

Three trials (Atkin 1995; Gebuhr 1992; Van Leemput 2007) included people with closed isolated fractures of the mid and distal ulnar shaft and excluded those of the proximal shaft. Three of the 29 isolated ulnar shaft fractures in Leung 2003 were open fractures.

Three trials compared conservative treatment options. Atkin 1995 compared three treatment groups: Ace wrap elastic bandages, short arm plaster casts and long arm plaster casts. Gebuhr 1992 compared the use of short arm pre-fabricated functional braces and long arm plaster casts. Van Leemput 2007 compared three treatment groups: immediate mobilisation, below elbow (short arm) plaster casts and above elbow (long arm) plaster casts.

We failed to locate any randomised trials comparing surgical with conservative treatment.

Leung 2003 compared two types of plates used in open reduction and internal fixation of fractures: the point contact fixator (PcFix) versus the limited contact dynamic compression plate (LCDCP).

Further details of these four trials are given in the 'Characteristics of included studies'.

\section{Excluded studies}

Details of the reasons for excluding seven other studies are given in the 'Characteristics of excluded studies'.

\section{Risk of bias in included studies}

All four trials were methodologically flawed and were at risk of serious bias. Table 3 shows the grades obtained by each of the four trials for the 11 items defined in Table 1 . As well as the Risk of bias table entries for individual trials in the 'Characteristics of included studies', an overall summary is available in Figure 1. 
Figure I. Risk of bias summary

\begin{tabular}{|c|c|c|c|c|c|c|c|c|c|}
\hline & 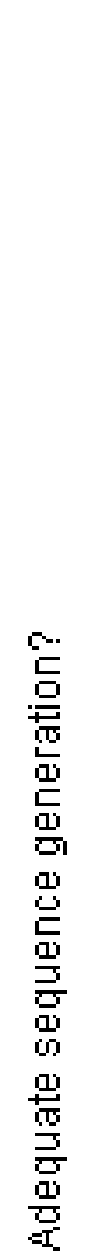 & 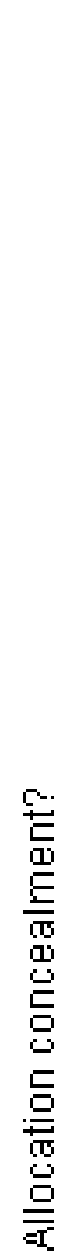 & 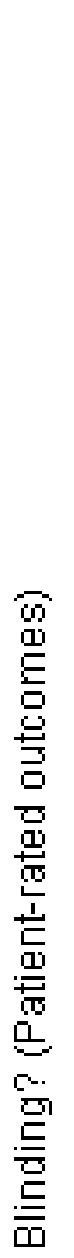 & 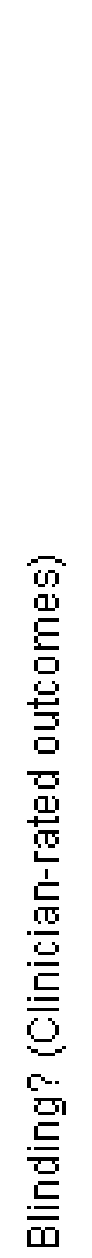 & 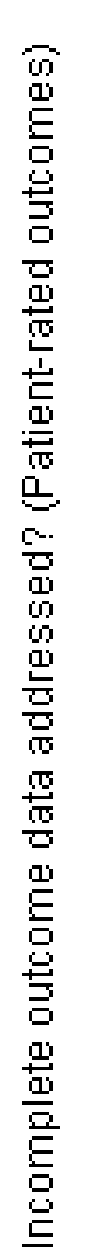 & 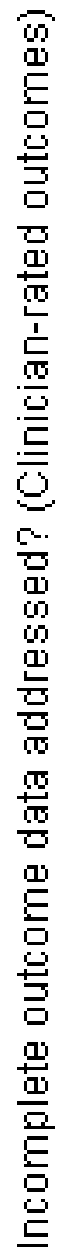 & 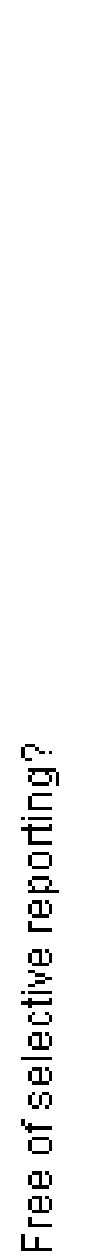 & 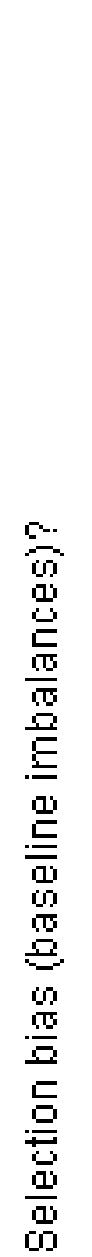 & 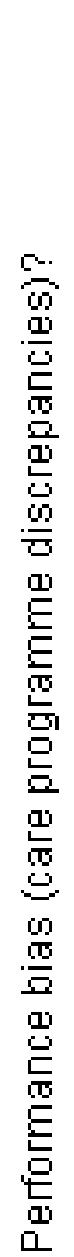 \\
\hline A.tkin 1995 & & - & 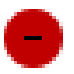 & $?$ & - & $?$ & $?$ & - & $?$ \\
\hline Gebuhr 1992 & + & $?$ & - & $?$ & + & $?$ & $?$ & $?$ & $?$ \\
\hline Leung 2003 & & 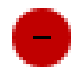 & $?$ & $?$ & $?$ & $?$ & $?$ & $?$ & $?$ \\
\hline Van Leemput 2007 & & 0 & & $?$ & $?$ & ? & $?$ & + & ? \\
\hline
\end{tabular}


Table 3. Methodological quality assessment results for individual trials

\begin{tabular}{|c|c|c|c|c|}
\hline Items / Trials & Atkin 1995 & Gebuhr 1992 & Leung 2003 & Van Leemput 2007 \\
\hline $\begin{array}{l}\text { 1. Allocation conceal- } \\
\text { ment }\end{array}$ & $\mathrm{N}$ & $?$ & $\mathrm{~N}$ & $\mathrm{~N}$ \\
\hline $\begin{array}{l}2 . \quad \text { Intention-to-treat } \\
\text { analysis }\end{array}$ & $\mathrm{N}$ & $\mathrm{N}$ & $?$ & $\mathrm{~N}$ \\
\hline 3. Assessor blinding & $\mathrm{N}$ & $\mathrm{N}$ & $\mathrm{N}$ & $\mathrm{N}$ \\
\hline $\begin{array}{l}\text { 4. Baseline characteris- } \\
\text { tics comparability }\end{array}$ & $\mathrm{N}$ & $\mathrm{N}$ & $?$ & Y \\
\hline 5. Participant blinding & $\mathrm{N}$ & $\mathrm{N}$ & $\mathrm{N}$ & $\mathrm{N}$ \\
\hline $\begin{array}{l}\text { 6. Treatment provider } \\
\text { blinding }\end{array}$ & $\mathrm{N}$ & $\mathrm{N}$ & $\mathrm{N}$ & $\mathrm{N}$ \\
\hline $\begin{array}{l}\text { 7. Care programme } \\
\text { comparability }\end{array}$ & $\mathrm{N}$ & $\mathrm{N}$ & $?$ & $?$ \\
\hline $\begin{array}{l}\text { 8. Inclusion and exclu- } \\
\text { sion criteria }\end{array}$ & $?$ & Y & Y & Y \\
\hline $\begin{array}{l}\text { 9. Well defined outcome } \\
\text { measures }\end{array}$ & $\mathrm{Y}$ & $\mathrm{Y}$ & Y & Y \\
\hline $\begin{array}{l}\text { 10. Clinically useful di- } \\
\text { agnostic tests }\end{array}$ & $\mathrm{Y}$ & Y & Y & $?$ \\
\hline $\begin{array}{l}\text { 11. Adequate duration of } \\
\text { follow-up }\end{array}$ & $?$ & $?$ & Y & $?$ \\
\hline
\end{tabular}

$\mathrm{Y}=$ yes; ? = partial/unknown; $\mathrm{N}=$ no

* Assessments for items 9, 10 and 11 relate to the outcome of fracture non-union. 
Copyright () 2009 The Cochrane Collaboration. Published by John Wiley \& Sons, Ltd. 


\section{Allocation}

Neither Atkin 1995 nor Gebuhr 1992 reported the method of randomisation adequately, but Atkin 1995 was quasi-randomised being based on the order of hospital admission. In response to a request for further information, Gebuhr 1992 reported using a computer program to generate random numbers but gave no assurance of allocation concealment. Leung 2003 changed their method from open randomisation lists to "strict" alternation around a third way through the trial; allocation was clearly not concealed at any stage of this trial. Treament allocation in Van Leemput 2007 was also not concealed; even if "strictly randomised" according to the date of presentation at the hospital. We judged there was a high risk of selection bias in all three quasi-randomised trials (Atkin 1995; Leung 2003; Van Leemput 2007).

\section{Blinding}

No mention of assessor blinding was made in any of the trial reports; there was, however, independent assessment of anatomical reduction in Leung 2003. Aside from the comparison of surgical devices in Leung 2003, we decided that there was a risk of bias for patient-rated outcomes for comparisons of conservative interventions but that clinician-rated outcomes, based on objective criteria, were probably less susceptible to bias.

\section{Incomplete outcome data}

The loss to follow-up (48\%) was severe in Atkin 1995. Though the trialists acknowledged this and stated that last attended clinic visits and X-rays before loss to follow-up revealed that the outcomes for these trial participants were not significantly different to those followed up to fracture union, the problem of bias remains. Atkin 1995 considered such large losses were a function of the indigent population and often violent cause of this injury. Gebuhr 1992 lost seven people (15\%) to follow-up. There appeared to be no loss to follow-up at 12 months in Leung 2003; though losses did occur subsequently. Similarly, there appeared to be no loss to follow-up from Van Leemput 2007, but this has not been confirmed.

\section{Selective reporting}

While there was insufficient information to permit judgement, we considered that this was not an issue for any of the included trials, all of which report on a typical set of outcomes for these fractures.

\section{Other potential sources of bias}

\section{Selection bias}

Incomplete information was provided for baseline characteristics in both Atkin 1995 and Gebuhr 1992. However, in both these trials, the distribution of fracture types (location, displacement and pattern) for those followed up was comparable between treatment groups. Aside from open and closed fractures, no specific information on fracture type was provided by Leung 2003; however, other patient characteristics were roughly comparable in the two groups in this trial. Assuming no loss to follow-up in Van Leemput 2007, baseline characteristics were similar in the three groups and thus this trial was probably free from confounding due to baseline differences.

\section{Performance bias}

There were insufficient details of the care provided to trial participants other than the trial interventions. Differences between the trial groups in the scheduling of follow-up could affect trial outcome but we decided the risk of performance bias was 'unclear' for all four trials.

\section{Detection bias}

While not explicitly assessed via the Risk of bias tool, ascertainment bias could result from difference in the follow-up assessments for the trial groups (this could occur through lack of active and systematic follow-up).

There was clearly active surveillance in Leung 2003 and Van Leemput 2007. While surveillance also appeared active for Atkin 1995 and Gebuhr 1992, neither reported a satisfactory systematic approach with set follow-up times. Atkin 1995 did not provide details of the frequency or timing of follow-up visits. Trial participants were seen at two to four week intervals in Gebuhr 1992; this variation in the times of assessment could potentially distort the findings of this trial.

In Atkin 1995 and Gebuhr 1992, the length of follow-up was based on the time for radiographically evident union and lack of pain. In Atkin 1995, the mean follow-up time was 20 weeks, whereas 20 weeks was the maximum follow-up in Gebuhr 1992. After a set follow up of 12 months in Leung 2003, the final follow-up ranged from 14 to 40 months and was partly dependent on whether the implant was removed. Follow-up in Van Leemput 2007 was 12 weeks.

\section{Effects of interventions}

The outcomes reported by the four studies are listed in ' Characteristics of included studies'. The small number of people involved, inadequate data and problems resulting from large losses to follow-up meant that graphical presentation of the trial results was considered inappropriate for Atkin 1995 and Gebuhr 1992. However, where possible the data were tested for statistical significance, partly to check the claims within the trial reports. The data for Leung 2003 are presented, in part because these would not be available otherwise. Few data were available for presentation in Van Leemput 2007, which is reported under two comparisons below: immediate mobilisation versus plaster cast immobilisation; and short arm plaster cast versus long arm plaster cast immobilisation.

\section{Immediate mobilisation versus plaster cast} immobilisation 
Van Leemput 2007 found no differences in outcome between immediate mobilisation (compression bandage supplied) versus cast immobilisation (short arm or long arm plaster casts) in adults with minimally displaced isolated ulnar shaft fractures. Specifically, there was no difference in the incidence of delayed union (Analysis 1.1. 4/34 versus 9/68; risk ratio (RR) 0.89 , 95\% confidence interval (CI) 0.29 to 2.68); nor in the time to union in the remaining trial participants (10.4 weeks versus 10.6 weeks). There were also no differences between the two groups in mean pain scores (8.62 versus 8.67 ; scale $0=$ worst pain, $10=$ no pain); mean loss of rotation $\operatorname{arc}\left(5.53^{\circ}\right.$ versus $\left.6.29^{\circ}\right)$ and mean loss of flexion/extension $\operatorname{arc}\left(4.33^{\circ}\right.$ versus $\left.4.58^{\circ}\right)$.

\section{Short arm pre-fabricated functional brace versus long arm plaster cast}

Gebuhr 1992 reported a median time of fracture healing of 56 days for the pre-fabricated functional brace group compared with 50 days for the long arm plaster cast group. This small difference was reported as not being statistically different and all fractures had healed by 20 weeks. Data for range of motion outcomes were not available for analysis but the wrist extension/flexion results for the brace group were reported to be significantly better $(P<0.004)$. Significantly more people returned to work while using the brace than the cast (non return to work: $1 / 14$ versus 12/13; RR 0.08 , $95 \%$ CI 0.01 to 0.51 ). Patient satisfaction with the device was also significantly greater in the brace group: an excellent grade being given for 14 out of 20 in the brace group compared with only one out of 19 in the cast group.

\section{Short arm plaster cast versus long arm plaster cast immobilisation}

Atkin 1995 reported a mean fracture union time of 7.9 weeks (14 people) for the short arm plaster cast group compared with 7.2 weeks (8 people) for the long arm cast group. A "significant" loss of motion was reported in two people in the short arm cast group. No or inadequate data were available for range of motion or anatomical outcomes. Patient assessment based on interviews of pain, cosmetic deformity and overall evaluation were not significantly different in either group (pain: 6/13 versus $2 / 5$; cosmetic deformity: $2 / 11$ versus $0 / 5$; poor or fair result: $2 / 10$ versus $1 / 5$ ). Three people removed their cast prematurely (before union was confirmed) in the short arm cast but none in the long arm cast. Two people in each group were unable to return to their previous employment (2/14 versus $2 / 9$; RR $0.64,95 \%$ CI 0.11 to 3.78 ). Van Leemput 2007 found no differences in outcome between short arm plaster cast immobilisation versus long arm plaster cast immobilisation in adults with minimally displaced isolated ulnar shaft fractures. Specifically, there was no difference in the incidence of delayed union (Analysis $2.15 / 36$ versus 4/32; RR 1.11, 95\% CI 0.33 to 3.78); nor in the time to union in the remaining trial participants (10.5 weeks versus 10.7 weeks). There were also no differences between the two groups in mean pain scores (8.69 versus 8.62 ; scale $0=$ worst pain, $10=$ no pain); mean loss of rotation arc $\left(5.86^{\circ}\right.$ versus $\left.6.66^{\circ}\right)$ and mean loss of flexion/extension $\operatorname{arc}\left(4.50^{\circ}\right.$ versus $\left.4.68^{\circ}\right)$.

\section{Ace Wrap elastic bandage}

Six out of the eight people allocated Ace wrap and followed up in Atkin 1995, changed to another treatment due to pain. Three were given short arm casts and the other three long arm casts. Although intention-to-treat results were provided for this group, this failure of treatment is the primary outcome.

\section{Point contact fixator (PC-Fix) versus the limited contact dynamic compression plate (LC-DCP)}

Twenty-nine out of the 93 people with forearm fractures recruited into Leung 2003 had isolated fracture of the ulna. The two surgeons performing the operations, both of whom were experienced in using both implants, reported similar amounts of ease or difficulty with both implants. The mean operating time was lower in the PC-Fix group (64 versus 78 minutes); this parallels the results for all forearm fractures (78 versus 92 minutes): the latter difference was reported not to be statistically significant. All fractures united but one person in the PC-Fix group and two people in the LC-DCP group had delayed union; all three had had closed fractures (Analysis 3.1). Precise anatomical reduction of fracture fragments was not achieved in 10 PC-Fix group participants and five LC-DCP group participants (Analysis 3.2). Two people in the PC-Fix group had pain at follow-up. All participants had "full" range of motion; defined as less than $10 \%$ loss of dorsiflexionpalmar flexion of the wrist and less than $25 \%$ loss of pronationsupination. Three participants had complications: a deep infection occurred in one person in the LC-DCP group (implant removal was not required); one person in the PC-Fix group had a superficial infection; and one person in the LC-DCP group developed compartment syndrome (Analysis 3.3). There was no nerve injury and none of the people who had had their implant removed at a later date sustained a refracture. As can be seen from the analyses, none of the differences reached statistical significance.

\section{DISCUSSION}

\section{Summary of main results}

Although the absence of strictly comparable interventions and fracture types precluded pooling of data, we found no evidence that cast immobilisation of the elbow offers a short-term advantage in respect of pain relief or fracture union compared with the use of casts or braces which immobilise only the forearm. Participants allocated to a functional forearm brace in Gebuhr 1992 returned to work significantly sooner than those wearing an above elbow cast. The efficacy of an elastic forearm wrap rather than forearm cast 
immobilisation remains unclear. We found no randomised trial comparing surgical versus conservative treatment. Where surgical fixation is considered appropriate, there is no evidence to support any particular implant type.

\section{Overall completeness and applicability of evidence}

The most common mechanism for these fractures is a direct hit on the forearm and these fractures are often sustained when the forearm is raised to fend off blows or when trying to protect the head. Forty-six per cent of the injuries in Gebuhr 1992 were attributed to violence and the large loss to follow-up in Atkin 1995 was considered to be a function of the often violent cause of this injury. However, an osteoporotic basis for those fractures that result from a simple fall in older females is also indicated in McQueen 2000. The majority of fractures in Leung 2003 and Van Leemput 2007 were reported as resulting from low trauma, the latter trial attributing all fractures as resulting from a direct hit on the forearm. Despite the differences in location and clear variation in the populations of the included trials, their results are likely to apply more generally.

However, in all three conservative treatment trials, interventions were poorly defined and the absence of strictly comparable interventions and fracture types precluded pooling of data. Two trials, Atkin 1995 and Van Leemput 2007, reported pain outomes when comparing a forearm elastic wrap (or compression bandage) with a cast, and came to different conclusions. In Atkin 1995, the majority of participants allocated to an Ace wrap requested a change to another treatment because of pain. In Van Leemput 2007, pain scores showed no significant difference between groups. It is unclear why this should be, but it may reflect the impact of differences in the context in which each study was conducted (Hawe 2004). More data on this comparison would be useful.

While we have not found any randomised trial comparing surgical versus conservative treatment, and thus are unable to define when surgical intervention is indicated, we were able to include a trial comparing two types of plate fixation. Leung 2003, however, was underpowered and the results of both the main trial and those of the subgroup of isolated ulnar shaft fractures, presented in this review, do not reveal statistically significant differences between the two implants. The two plates, both made of titanium, under comparison in this trial are manufactured by the same company and represent interim stages in a sequence of technological developments by the associated AO Research Institute (Perren 1995; Perren 2003). Further developments in plating technology may preclude the use of these two specific plates in the future (Smith 2004), a point discussed in subsequent correspondence on this trial (Rajasekhar 2004).

\section{Quality of the evidence}

All four trials included in this review had methodological weaknesses that makes them highly susceptible to bias. Three were quasi-randomised, and there was no assurance of allocation concealment for the only trial that had adequate sequence generation. There was no blinding of outcome assessment, and in Atkin 1995, almost half the participants were lost to follow-up. The absence of information on loss to follow-up in Van Leemput 2007 is a concern.

\section{Potential biases in the review process}

We think that it is unlikely that the review process itself has introduced bias. We did not conduct a meta-analysis, and have reported the potential biases associated with the studies themselves. We believe that publication bias is unlikely; the search was comprehensive, and included the bibliography of a large narrative review ( Mackay 2000).

\section{Agreements and disagreements with other studies or reviews}

We found two relevant reviews. Mackay 2000 provided an useful compilation of the literature and summary of the treatment methods used in studies from the 1950s onwards, and included data from 33 mainly retrospective case reporting the outcomes from 1876 people. Methods used in Mackay 2000 for combining the results of groups of people who were given the same treatment were not optimal; for instance, confidence limits were not provided for estimated effects. In addition, although study design and some aspects of study methodology were noted in their appraisal of individual studies, the potential for systematic bias arising from flawed study methodology was not explored or discussed. A formal critique of Mackay 2000 may be found in DARE (Database of Abstracts of Reviews of Effects) (DARE 2006). The quantitative results of Mackay 2000 should be viewed with caution and should not be taken as the basis for comparisons of effectiveness of the various treatments covered in the review.

A more recent review (Bhandari 2004), which reviewed evidence from randomised studies only, found the same three randomised trials published before 2004 as included in the concurrent version of this review, and reached similar conclusions.

\section{AUTHORS' CONCLUSIONS}

\section{Implications for practice}

Overall, there is insufficient evidence from randomised controlled trials to determine which method of treatment is the most appropriate for the treatment of isolated fractures of the ulnar shaft in adults. There is, however, weak evidence that in people with minimally displaced isolated fracture of the ulna, cast immobilisation 
of the elbow may offer no short-term advantage in respect of pain relief or fracture union, and may be associated with longer delay in return to work, when compared with the use of a cast or brace that immobilises only the forearm.

\section{Implications for research}

Though isolated ulnar shaft fractures are comparatively uncommon there remains a need to establish the best methods to manage these fractures, which are often associated with a high rate of complications and, for some people, significant life changes. The limited information on incidence, and choice, cost, and outcome of treatment, hampers an appraisal of what priority needs to be given to research in this area. However, given that most fractures are treated conservatively and the availability of only weak RCT evidence, the use of splintage and the inclusion or not of the elbow in splintage for minimally displaced fractures appear to be suitable candidates for future randomised trials. All future research should meet robust contemporary standards of design conduct, and reporting, including the use of randomisation methods involving stratification, to ensure baseline equivalence between treatment groups in respect of fracture pattern, location of the fracture, and bone quality.

\section{ACKNOWLEDGEMENTS}

We would like to express our thanks to Mr Amar Rangan for his early encouragement and Prof William Gillespie for his comments on an earlier draft. We thank Mr Agop der Tavitian for his contribution to the first version of the review. We would also like to thank the following for their useful comments at editorial review of one or more versions of this review: Prof William Gillespie, Assoc Prof Peter Herbison, Mr Geoffrey Hooper, Dr Vicki Livingstone, Prof Rajan Madhok, Prof Gordon Murray, Prof Marc Swiontkowski and Dr Janet Wale. We thank the following for their help during the editorial review of successive updates: Dr Joanne Elliott, Mrs Lindsey Elstub, Mrs Lesley Gillespie, Prof William Gillespie, Ms Leeann Morton and Ms Kate Rowntree.

We thank Mrs Sonia Stewart for translating two articles.

We are grateful to Jo Kamen for providing separate data for isolated ulnar fractures for Leung 2003; and to Mr Tom Van Leemput for providing information on Van Leemput 2007.

Dr Helen Handoll's work on the first two versions of the review was supported by the Chief Scientist Office, Department of Health, The Scottish Office, UK.

\section{R E F E R E N C E S}

\section{References to studies included in this review}

Atkin 1995 \{published data only\}

Atkin DM, Bohay DR, Slabaugh P, Smith BW. Treatment of ulnar shaft fractures: A prospective, randomised study. Orthopedics 1995; 18(6):543-7. [MEDLINE: 1995406131]

Gebuhr 1992 \{published and unpublished data\} Gebuhr P, Holmich P, Orsnes T, Soelberg M, Krasheninnikoff M, Kjersgaard AG. Isolated ulnar shaft fractures: Comparison of treatment by a functional brace and long-arm cast. Journal of Bone and Joint Surgery - British Volume 1992;74(5):757-9. [MEDLINE: 1992406976]

Leung 2003 \{published and unpublished data\}

Kamen J. personal communication January 132004.

${ }^{*}$ Leung F, Chow S-P. A prospective, randomized trial comparing the limited contact dynamic compression plate with the point contact fixator for forearm fractures. Journal of Bone and Joint Surgery - American Volume 2003;85(12):2343-8.

Rajasekhar C, Goyal R, Leung F, Chow S-P. Fixation of forearm fractures [letter and reply]. Journal of Bone and Joint Surgery American Volume 2004;86-A(8):1830.

Van Leemput 2007 \{published data only\}

Van Leemput T. personal communication December 312008.

* Van Leemput T, Mahieu G. Conservative management of minimally displaced isolated fractures of the ulnar shaft. Acta Orthopaedica Belgica 2007;73(6):710-3.

\section{References to studies excluded from this review}

Buch 1989 \{published data only\}

Buch J, Hoffmann G. Functional treatment of ulnar shaft breakages [Funktionelle behandlung von ellenschaftbruchen]. Hefte zur Unfallheikunde 1989;201:149-51.

Chirstos 2002 \{published and unpublished data\}

Chirstos CG. personal communication October 312002.

* Chirstos CG. Forearm bone non-union and its management. Ethiopian Medical Journal 2002;40(1):53-8.

Collinge 2000 \{published data only\} Collinge CA, Herscovici D. Open reduction and plating vs. intramedullary nailing for diaphyseal forearm fractures: A prospective randomized study [abstract]. Journal of Orthopaedic Trauma 2000;14(2):121.

Goel 1991 \{published data only\} Goel SC, Raj KB, Srivastava TP. Isolated fractures of the ulnar shaft. Injury 1991;22(3):212-4.

Labbe 1998 \{published data only\} Labbe JL, Leclair O, Goulon R. The treatment of fractures of the shaft of the ulna by closed percutaneous pinning [Abstract]. Journal of Bone and Joint Surgery - British Volume 1997;79 Suppl 1:62. Labbe JL, Peres O, Leclair O, Goulon R, Bertrou V. Isolated fractures of the adult ulnar shaft; treatment by percutaneous intramedullary nailing versus plate fixation (AO) [Abstract]. Journal of Bone and Joint Surgery - British Volume 1996;78 Suppl 2 \& 3:108.

* Labbe JL, Peres O, Leclair O, Goulon R, Bertrou V, Saint-Lanne $\mathrm{S}$. Fixation of isolated ulnar shaft fracture by open reduction and 
internal fixation with plate or percutaneous intramedullary nailing [La fracture isolee de la diaphyse ulnaire, de l'osteosynthese par plaque a l'embrochage centro-medullaire]. Revue de Chirurgie Orthopedique et Reparatrice de l'Appareil Moteur 1998;84(6): 515-22.

Piatek 2000 \{published data only\}

Piatek S, Westphal T, Schubert S, Winckler S. Sealing nailing versus plate osteosynthesis in diaphysaric lower arm fractures

[Verriegelungsnagelung versus plattenosteosynthese bei diaphysaren unterarmfrakturen]. Hefte zur der Unfallchirurg 2000;282:427-8.

Skinner 1989 \{published data only\} Skinner M, Szabo RM. Isolated ulna shaft fractures [Abstract]. Orthopaedic Transactions 1989;13(3):530.

\section{Additional references}

\section{Atkin 1995a}

Atkin DM, Bohay DR, Slabaugh P, Smith BW. Treatment of ulnar shaft fractures: A prospective, randomized study. Orthopedics 1995; 18(6):543-7.

\section{Beaton 2001}

Beaton DE, Katz JN, Fossel AH, Wright JG, Tarasuk V, Bombardier C. Measuring the whole or the parts? Validity, reliability, and responsiveness of the disabilities of the arm, shoulder and hand outcome measure in different regions of the upper extremity. Journal of Hand Therapy 2001;14(2):128-46.

\section{Bhandari 2004}

Bhandari M, Schemitsch EH. Fractures of the shaft of the ulna. Journal of Orthopaedic Trauma 2004;18(7):473-5.

\section{DARE 2006}

Centre for Reviews and Dissemination. The treatment of isolated ulnar fractures in adults: a systematic review (Structured abstract). Database of Abstracts of Reviews of Effects: DARE-20001826. In The Cochrane Library 2006; Vol. 3.

\section{De Jong 1989}

De Jong T, De Jong PCM. Ulnar-shaft fracture needs no treatment. A pilot study of 10 cases. Acta Orthopaedica Scandinavica 1989;60 (3):263-4.

\section{Du Toit 1979}

Du Toit FP, Grabe RP. Isolated fractures of the shaft of the ulna. South African Medical Journal 1979;56(1):21-5.

\section{Grace 1980}

Grace TG, Witmer BJ. Isolated fractures of the ulnar shaft [abstract]. Orthopaedic Transactions 1980;4:299.

\section{Hawe 2004}

Hawe P, Shiell A, Riley T, Gold L. Methods for exploring implementation variation and local context within a cluster randomised community intervention trial. Journal of Epidemiology and Community Health 2004;58(9):788-93.

\section{Higgins 2006}

Higgins JPT, Green S, editors. Highly sensitive search strategies for identifying reports of randomized controlled trials in MEDLINE. Cochrane Handbook for Systematic Reviews of Interventions 4.2.6 [updated September 2006]; Appendix 5b. www.cochrane.org/ resources/handbook/hbook.htm (accessed 14 Nov 2006).

\section{Higgins 2008}

Higgins JPT, Altman DG (editors). Chapter 8: Assessing risk of bias in included studies Table 8.5a. Chapter 8: Assessing risk of bias in included studies. In: Higgins JPT, Green S (editors). Cochrane Handbook for Systematic Reviews of Interventions Version 5.0.1 (updated September 2008). The Cochrane Collaboration, 2008. Available from www.cochrane-handbook.org.

\section{Mackay 2000}

Mackay D, Wood L, Rangan A. The treatment of isolated ulnar fractures in adults: a systematic review. Injury 2000;31(8):565-70.

\section{McQueen 2000}

McQueen MM. Epidemiology of fractures of the radius and ulna. In: McQueen MM, Jupiter JB editor(s). Radius and ulna. Oxford: Butterworth Heinemann, 2000:1-11.

\section{Perren 1995}

Perren SM, Buchanan JS. Basic concepts relevant to the design and development of the point contact fixator (PC-Fix). Injury 1995;26 (Suppl 2):SB1-4.

\section{Perren 2003}

Perren SM. Backgrounds of the technology of internal fixators. Injury 2003;34(Suppl 2):SB1-3.

\section{Pollock 1983}

Pollock FH, Pankovich AM, Prieto JJ, Lorenz M. The isolated fracture of the ulnar shaft. Treatment without immobilization. Journal of Bone and Joint Surgery - American Volume 1983;65(3): $339-42$.

\section{Rajasekhar 2004}

Rajasekhar C, Goyal R, Leung F, Chow S-P. Fixation of forearm fractures [letter and reply]. Journal of Bone and Joint Surgery American Volume 2004;86-A(8): 1830.

\section{Smith 2004}

Smith RM. Commentary \& Perspective on "A prospective, randomized trial comparing the limited contact dynamic compression plate with the point contact fixator for forearm fractures". http://www.jbjs.org/Comments/2004/ cp'jan04'smith.shtml (accessed 15/01/04).

\section{Swiontkowski 1999}

Swiontkowski MF, Engelberg R, Martin DP, Agel J. Short Musculoskeletal Function Assessment Questionnaire: validity, reliability, and responsiveness. Journal of Bone and Joint Surgery American Volume 1999;81(9):1245-60.

* Indicates the major publication for the study 


\section{CHARACTERISTICS OF STUDIES}

\section{Characteristics of included studies [ordered by study ID]}

Atkin 1995

\begin{tabular}{|c|c|c|}
\hline Methods & \multicolumn{2}{|c|}{$\begin{array}{l}\text { Randomisation by order of hospital admission } \\
\text { Assessor blinding: not stated } \\
\text { Intention-to-treat analysis: only for those followed up } \\
\text { Loss to follow-up: } 29 \text { (48\%) }\end{array}$} \\
\hline Participants & \multicolumn{2}{|c|}{$\begin{array}{l}\text { Highland General Hospital, University of California, USA } \\
60 \text { participants. Of } 31 \text { analysed: } 22 \text { male ( } 71 \%) \text {, mean age } 35 \text { years, range 19-50 years } \\
\text { Transverse, oblique, comminuted, and displaced fractures included. } \\
\text { Inclusion criteria: closed midshaft, or distal isolated ulnar fracture. } \\
\text { Exclusion criteria: proximal ulnar fracture, distal radioulnar fracture. }\end{array}$} \\
\hline Interventions & \multicolumn{2}{|c|}{$\begin{array}{l}\text { No details of when treatment started. Infer that treatment ended when fracture union } \\
\text { confirmed. } \\
\text { 1. Ace Wrap - elastic bandage } \\
\text { 2. Short arm plaster cast } \\
\text { 3. Long arm plaster cast } \\
\text { Allocated: ?/?/? (numbers in each group not stated) } \\
\text { Assessed: } 8 / 14 / 9 \text { (subjective results: } 7 / 10 / 5 \text { ) }\end{array}$} \\
\hline Outcomes & \multicolumn{2}{|c|}{$\begin{array}{l}\text { Length of follow-up: until union (mean } 20 \text { weeks) } \\
\text { Fracture union (radiographic and pain free) } \\
\text { Treatment failure } \\
\text { Patient evaluation: pain, cosmetic deformity, satisfaction. } \\
\text { Range of motion (wrist, elbow, forearm) } \\
\text { Anatomic: varus and volar/dorsal angulation } \\
\text { Return to previous employment }\end{array}$} \\
\hline Notes & \multicolumn{2}{|c|}{$\begin{array}{l}\text { Large loss of follow-up attributed to common violent origin of this fracture. } \\
\text { Six participants did not tolerate Ace wrap due to pain: } 3 \text { were changed to short arm } \\
\text { plaster casts and } 3 \text { to long arm plaster casts. }\end{array}$} \\
\hline \multicolumn{3}{|l|}{ Risk of bias } \\
\hline Item & Authors' judgement & Description \\
\hline Adequate sequence generation? & No & $\begin{array}{l}\text { "Based on order of hospital admission", } \\
\text { thus quasi-randomised. }\end{array}$ \\
\hline Allocation concealment? & No & $\begin{array}{l}\text { Inadequate because "based on order of hos- } \\
\text { pital admission". }\end{array}$ \\
\hline $\begin{array}{l}\text { Blinding? } \\
\text { Patient-rated outcomes }\end{array}$ & No & There was no report of blinding. \\
\hline
\end{tabular}


Atkin 1995 (Continued)

\begin{tabular}{|c|c|c|}
\hline $\begin{array}{l}\text { Blinding? } \\
\text { Clinician-rated outcomes }\end{array}$ & Unclear & There was no report of blinding. \\
\hline $\begin{array}{l}\text { Incomplete outcome data addressed? } \\
\text { Patient-rated outcomes }\end{array}$ & No & $\begin{array}{l}\text { Large loss to follow-up: } 29 / 60(48 \%) \text {. In- } \\
\text { adequate data available to examine effects. }\end{array}$ \\
\hline $\begin{array}{l}\text { Incomplete outcome data addressed? } \\
\text { Clinician-rated outcomes }\end{array}$ & Unclear & $\begin{array}{l}\text { Large loss to follow-up: } 29 / 60 \text { ( } 48 \%) \text {. In- } \\
\text { adequate data available to examine effects. }\end{array}$ \\
\hline Free of selective reporting? & Unclear & $\begin{array}{l}\text { Reports on typical set of outcomes for these } \\
\text { fractures. }\end{array}$ \\
\hline Selection bias (baseline imbalances)? & No & $\begin{array}{l}\text { Data not provided for whole study popu- } \\
\text { lation. Some imbalances in patient charac- } \\
\text { teristics of the } 31 \text { followed up (e.g. fracture } \\
\text { type). }\end{array}$ \\
\hline $\begin{array}{l}\text { Performance bias (care programme discrep- } \\
\text { ancies)? }\end{array}$ & Unclear & Insufficient information. \\
\hline
\end{tabular}

Gebuhr 1992

\begin{tabular}{|c|c|}
\hline Methods & $\begin{array}{l}\text { Randomisation used random numbers generated from the 'Medstat' program } \\
\text { Assessor blinding: not stated } \\
\text { Intention-to-treat analysis: only for those followed up } \\
\text { Loss to follow-up: } 7(15 \%)\end{array}$ \\
\hline Participants & $\begin{array}{l}\text { University hospitals, Denmark } \\
46 \text { participants. Of } 39 \text { analysed: } 19 \text { male ( } 49 \%) \text {, median age } 44 \text { years, range } 12-85 \text { years. } \\
\text { Transverse, oblique and comminuted fractures included. } \\
\text { Inclusion criteria: closed midshaft or distal isolated ulnar fracture. } \\
\text { Exclusion criteria: proximal ulnar fracture, Monteggia fracture dislocations }\end{array}$ \\
\hline Interventions & $\begin{array}{l}\text { Interventions started after initial immobilisation in an above elbow cast aimed to relieve } \\
\text { pain and allow swelling to subside. Interventions removed when healed. } \\
\text { 1. Short arm pre-fabricated functional brace } \\
\text { 2. Long arm plaster cast } \\
\text { Allocated: } 23 / 23 \\
\text { Assessed: } 20 / 19\end{array}$ \\
\hline Outcomes & $\begin{array}{l}\text { Length of follow-up: maximum } 20 \text { weeks } \\
\text { Fracture union (radiographic and pain free) } \\
\text { Patient evaluation: satisfaction, pain } \\
\text { Range of motion (wrist, elbow, forearm: elbow extension/flexion, forearm pronation/ } \\
\text { supination and wrist extension/flexion) } \\
\text { Anatomic: varus and volar/dorsal angulation } \\
\text { Return to previous employment, use of device at work }\end{array}$ \\
\hline
\end{tabular}


Gebuhr 1992 (Continued)

\begin{tabular}{|c|c|c|}
\hline Notes & \multicolumn{2}{|c|}{ Letter from Gebuhr gave details of the method of randomisation. } \\
\hline \multicolumn{3}{|l|}{ Risk of bias } \\
\hline Item & Authors' judgement & Description \\
\hline Adequate sequence generation? & Yes & $\begin{array}{l}\text { Randomisation "used random numbers } \\
\text { generated from the 'Medstat' program". }\end{array}$ \\
\hline Allocation concealment? & Unclear & $\begin{array}{l}\text { No confirmation of this: "allocated ran- } \\
\text { domly". }\end{array}$ \\
\hline $\begin{array}{l}\text { Blinding? } \\
\text { Patient-rated outcomes }\end{array}$ & No & There was no report of blinding. \\
\hline $\begin{array}{l}\text { Blinding? } \\
\text { Clinician-rated outcomes }\end{array}$ & Unclear & There was no report of blinding. \\
\hline $\begin{array}{l}\text { Incomplete outcome data addressed? } \\
\text { Patient-rated outcomes }\end{array}$ & Yes & $\begin{array}{l}\text { Moderate loss to follow-up: } 7 / 46(15 \%) \text {. } \\
\text { Six participants failed to attend follow-up } \\
\text { examinations but this is unlikely to affect } \\
\text { results. }\end{array}$ \\
\hline $\begin{array}{l}\text { Incomplete outcome data addressed? } \\
\text { Clinician-rated outcomes }\end{array}$ & Unclear & $\begin{array}{l}\text { Moderate loss to follow-up: } 7 / 46(15 \%) \text {. } \\
\text { Treatment group of person with putative } \\
\text { non-union who had operation not known. }\end{array}$ \\
\hline Free of selective reporting? & Unclear & $\begin{array}{l}\text { Reports on typical set of outcomes for these } \\
\text { fractures. }\end{array}$ \\
\hline Selection bias (baseline imbalances)? & Unclear & $\begin{array}{l}\text { Brace group were younger (mean age } 42 \\
\text { versus } 48 \text { years) but otherwise characteris- } \\
\text { tics of the participants included in the anal- } \\
\text { yses of the two groups seemed comparable. } \\
\text { However, data for } 7 \text { participants are miss- } \\
\text { ing. }\end{array}$ \\
\hline $\begin{array}{l}\text { Performance bias (care programme discrep- } \\
\text { ancies)? }\end{array}$ & Unclear & $\begin{array}{l}\text { Insufficient information - initial treatment } \\
\text { was the same and subsequent advice on ac- } \\
\text { tivity seemed similar too. }\end{array}$ \\
\hline
\end{tabular}




\begin{tabular}{ll} 
Methods & $\begin{array}{l}\text { Randomisation initially involved use of an open, predetermined randomisation chart } \\
\text { and then was changed to "strict" alternation } \\
\text { Assessor blinding: none; independent assessment of quality of reduction } \\
\text { Intention-to-treat analysis: yes, though data from one participant who withdrew imme- } \\
\text { diately post-randomisation were excluded and the numbers of participants in each group } \\
\text { at long-term follow-up were not reported } \\
\text { Loss to follow-up: } 10 \text { (11\%) of } 93 \text { in trial. }\end{array}$ \\
\hline Participants & $\begin{array}{l}\text { Queen Mary Hospital, University of Hong Kong, Hong Kong, China } \\
29 \text { participants (subgroup of } 93 \text { participants with forearm fractures): } 26 \text { male }(90 \%), \\
\text { mean age } 35 \text { years, range } 13-79 \text { years. Open (3) and closed fractures: }(21) ; 72 \% \text { from } \\
\text { low energy trauma. } \\
\text { Inclusion criteria: acute forearm shaft fracture in patients over } 10 \text { years old. } \\
\text { Exclusion criteria: pathological fracture, rheumatoid arthritis, history of long-term } \\
\text { steroid therapy, judged unlikely to complete follow-up, no consent. }\end{array}$
\end{tabular}

Interventions

Outcomes

Notes

No details of when surgery occurred except that it was performed after randomisation. All participants were admitted into hospital and received a single injection of antibiotic. Reduction mainly done via direct fracture manipulation - a distraction device was used in some cases. Both implants were titanium.

1. Point contact fixator (PC-Fix) - screws lock into screw-hole on plate and do not enter the cortical bone on the other side of the bone

2. Limited contact dynamic compression plate (LC-DCP) - screws cross through the bone to the other side from the plate and lock into bone rather than the plate

Allocated: $17 / 12$

Assessed: 17/12 (12 months)

Length of follow-up: (for whole trial population)mean 22 months (14-40 months) but also 2, 4 and 12 months

Fracture union (radiographic)

Pain (with and without load bearing)

Complications: infection, compartment syndrome, nerve injury (0), refracture on removal of implant (0), screw pull out (0)

Range of motion (wrist and forearm)

Anatomic reduction

Length of operation

Ease of fixation

Separate data for participants with isolated ulnar fracture obtained from trial investigators.

\section{Risk of bias}

\begin{tabular}{|c|c|c|}
\hline Item & Authors' judgement & Description \\
\hline Adequate sequence generation? & No & $\begin{array}{l}\text { "For the initial thirty-two cases, an open, } \\
\text { predetermined randomization chart was } \\
\text { used. The chart was constructed of blocks } \\
\text { containing four allocations. For the subse- }\end{array}$ \\
\hline
\end{tabular}


Leung 2003 (Continued)

\begin{tabular}{|c|c|c|}
\hline & & $\begin{array}{l}\text { quent cases, the choice of fixation was de- } \\
\text { termined in a strictly alternating fashion." } \\
\text { Hence, quasi-randomised. }\end{array}$ \\
\hline Allocation concealment? & No & $\begin{array}{l}\text { As above: "open" list and then alternation. } \\
\text { Hence no concealment of allocation. }\end{array}$ \\
\hline $\begin{array}{l}\text { Blinding? } \\
\text { Patient-rated outcomes }\end{array}$ & Unclear & No mention of blinding. \\
\hline $\begin{array}{l}\text { Blinding? } \\
\text { Clinician-rated outcomes }\end{array}$ & Unclear & $\begin{array}{l}\text { No mention of blinding. Independent ob- } \\
\text { server for judging anatomical reduction. }\end{array}$ \\
\hline $\begin{array}{l}\text { Incomplete outcome data addressed? } \\
\text { Patient-rated outcomes }\end{array}$ & Unclear & $\begin{array}{l}\text { Only pain assessed. Inadequate informa- } \\
\text { tion but all participants appear to have been } \\
\text { followed up. }\end{array}$ \\
\hline $\begin{array}{l}\text { Incomplete outcome data addressed? } \\
\text { Clinician-rated outcomes }\end{array}$ & Unclear & $\begin{array}{l}\text { Inadequate information but all participants } \\
\text { appear to have been followed up }\end{array}$ \\
\hline Free of selective reporting? & Unclear & $\begin{array}{l}\text { Reports on typical set of outcomes for these } \\
\text { fractures. }\end{array}$ \\
\hline Selection bias (baseline imbalances)? & Unclear & $\begin{array}{l}\text { Data provided for isolated ulnar fractures } \\
\text { indicated a reasonable balance. }\end{array}$ \\
\hline $\begin{array}{l}\text { Performance bias (care programme discrep- } \\
\text { ancies)? }\end{array}$ & Unclear & $\begin{array}{l}\text { Incomplete information. Both surgeons } \\
\text { were experienced with the devices. Slight } \\
\text { difference in use of open reduction: } 83 \% \\
\text { versus } 93 \% \text { for overall population. Similar } \\
\text { follow-up times. }\end{array}$ \\
\hline
\end{tabular}

Van Leemput 2007

\begin{tabular}{|c|c|}
\hline Methods & $\begin{array}{l}\text { Randomisation by date of hospital presentation (group } 1=1 \mathrm{st} \text {, } 4 \text { th, etc of each month; } \\
\text { group } 2=2 \mathrm{nd} \text {, } 5 \text { th, etc; group } 3=3 \mathrm{rd}, 6 \mathrm{th} \text {, etc). } \\
\text { Assessor blinding: not stated } \\
\text { Intention-to-treat analysis: probably yes, implied but no explicit statement on loss to } \\
\text { follow-up } \\
\text { Loss to follow-up: probably none but no confirmation received }\end{array}$ \\
\hline Participants & $\begin{array}{l}\text { Frere Hospital, East London, South Africa } \\
102 \text { participants: } 43 \text { male ( } 42 \%) \text {, mean age } 42 \text { years, range } 18-78 \text { years with a minimally } \\
\text { displaced ulnar shaft fracture. All fractures resulted from "focal low-energy trauma due } \\
\text { to a direct hit on the forearm". } \\
\text { Inclusion criteria: isolated minimally displaced ( }<50 \% \text { displacement)of the distal two- } \\
\text { thirds of the ulnar shaft. } \\
\text { Exclusion criteria: open or severely comminuted fracture, signs of infection, multiple }\end{array}$ \\
\hline
\end{tabular}


Van Leemput 2007 (Continued)

trauma, age $<18$ years.

\begin{tabular}{ll}
\hline Interventions & $\begin{array}{l}\text { No details of when treatment started, all treated on an outpatient basis. } \\
\text { 1. Immediate mobilisation - supplied with compression bandage } \\
\text { 2. Short arm (below elbow) plaster cast for } 6 \text { weeks } \\
\text { 3. Long arm (above elbow) plaster cast for } 3 \text { weeks, then } 3 \text { weeks in a below elbow cast } \\
\text { Allocated: } 34 / 36 / 32 \text { (assuming no losses) } \\
\text { Assessed: } 34 / 36 / 32\end{array}$ \\
\hline Outcomes & $\begin{array}{l}\text { Length of follow-up: } 12 \text { weeks, also at } 6 \text { and } 9 \text { weeks } \\
\text { Fracture union (delayed union assessed radiographically) } \\
\text { Patient evaluation: pain (Visual Analogue Scale: } 0=\text { worst to } 10=\text { none) } \\
\text { Range of motion (elbow extension/flexion, forearm rotation) } \\
\text { Anatomic: time to bony union }\end{array}$ \\
\hline Notes & $\begin{array}{l}\text { Details of method of randomisation, baseline characteristics and pain scale provided by } \\
\text { Van Leemput. }\end{array}$ \\
\hline
\end{tabular}

Risk of bias

\begin{tabular}{|c|c|c|}
\hline Item & Authors' judgement & Description \\
\hline Adequate sequence generation? & No & $\begin{array}{l}\text { "Patient selection in three different groups } \\
\text { was strictly randomised, purely based on } \\
\text { date of first presentation at the hospital.". } \\
\text { Thus, quasi-randomised. }\end{array}$ \\
\hline Allocation concealment? & No & Not concealed - quasi-randomised trial. \\
\hline $\begin{array}{l}\text { Blinding? } \\
\text { Patient-rated outcomes }\end{array}$ & No & No mention of blinding. \\
\hline $\begin{array}{l}\text { Blinding? } \\
\text { Clinician-rated outcomes }\end{array}$ & Unclear & No mention of blinding. \\
\hline $\begin{array}{l}\text { Incomplete outcome data addressed? } \\
\text { Patient-rated outcomes }\end{array}$ & Unclear & $\begin{array}{l}\text { Follow-up of all participants likely but not } \\
\text { confirmed. }\end{array}$ \\
\hline $\begin{array}{l}\text { Incomplete outcome data addressed? } \\
\text { Clinician-rated outcomes }\end{array}$ & Unclear & $\begin{array}{l}\text { Follow-up of all participants likely but not } \\
\text { confirmed. Four participants in each group } \\
\text { excluded from range of motion analyses be- } \\
\text { cause of prior fracture in the contralateral } \\
\text { arm. }\end{array}$ \\
\hline Free of selective reporting? & Unclear & $\begin{array}{l}\text { Reports on typical set of outcomes for these } \\
\text { fractures. }\end{array}$ \\
\hline Selection bias (baseline imbalances)? & Yes & $\begin{array}{l}\text { Baseline characteristics provided by Van } \\
\text { Leemput showed sufficient similarity in }\end{array}$ \\
\hline
\end{tabular}


Van Leemput 2007 (Continued)

age, sex and dominant side injury.

Performance bias (care programme discrep- Unclear

Insufficient information. Similar follow-up ancies)?

times and advice on pain. 


\section{Characteristics of excluded studies [ordered by study ID]}

Buch 1989 Comparative study of functional treatments and immobilisation for 124 people with isolated ulnar shaft fracture.
Translation from German showed it was not randomised.

Chirstos 2002 Author confirmed that some of the 125 people with forearm bone compound fractures resulting from missile injuries had isolated ulnar shaft fractures. He also explained that the use of the term "at random" in the abstract of the report did not refer to a randomised trial but that there was a "lack of standard management and implements to dictate management protocol".

Collinge 2000 Randomised trial comparing open reduction and plating with intramedullary nailing in 36 people with 37 diaphyseal forearm fractures, six of whom only had ulnar fractures. The sample size, which may have been further reduced through inadequate follow up, of people with isolated fractures of the ulnar shaft was considered too small to pursue separate data for these patients.

Goel 1991 Comparative prospective study of 89 people with 90 isolated ulna fractures who were treated with either plaster cast splintage ( 45 fractures)or elastic crepe bandage support and early mobilisation ( 45 fractures). It is not clear how the two groups were derived. Only 60 people were followed up. There was no response to a request for further information sent to the authors in March 1999.

Labbe 1998 Abstract only. Authors confirmed (reply March 1998) that this was a retrospective study but also indicated that they were working on a randomised study of the same comparison.

Piatek 2000 Randomised trial of nailing versus plate fixation for closed fractures in the middle third of both lower arm bones in 11 people. Not isolated ulnar shaft fractures.

Skinner 1989 Abstract initially downloaded from web. However the full abstract in Orthopaedic Transactions confirmed this was not a randomised trial. 
DATA AND ANALYSES

Comparison 1. Immediate mobilisation versus plaster cast immobilisation

\begin{tabular}{|c|c|c|c|c|}
\hline Outcome or subgroup title & $\begin{array}{l}\text { No. of } \\
\text { studies }\end{array}$ & $\begin{array}{c}\text { No. of } \\
\text { participants }\end{array}$ & Statistical method & Effect size \\
\hline 1 Delayed union (at 12 weeks) & 1 & & Risk Ratio (M-H, Fixed, 95\% CI) & Totals not selected \\
\hline
\end{tabular}

Comparison 2. Short arm plaster cast versus long arm plaster cast immobilisation

\begin{tabular}{|c|c|c|c|c|}
\hline Outcome or subgroup title & $\begin{array}{l}\text { No. of } \\
\text { studies }\end{array}$ & $\begin{array}{c}\text { No. of } \\
\text { participants }\end{array}$ & Statistical method & Effect size \\
\hline 1 Delayed union (at 12 weeks) & 1 & & Risk Ratio (M-H, Fixed, 95\% CI) & Totals not selected \\
\hline
\end{tabular}

Comparison 3. Point contact fixator (PC-Fix) versus the limited contact dynamic compression plate (LC-DCP)

\begin{tabular}{|c|c|c|c|c|}
\hline Outcome or subgroup title & $\begin{array}{l}\text { No. of } \\
\text { studies }\end{array}$ & $\begin{array}{c}\text { No. of } \\
\text { participants }\end{array}$ & Statistical method & Effect size \\
\hline 1 Anatomical outcomes & 1 & & Risk Ratio (M-H, Fixed, 95\% CI) & Totals not selected \\
\hline 1.1 Non-union & 1 & & Risk Ratio (M-H, Fixed, 95\% CI) & Not estimable \\
\hline 1.2 Delayed union & 1 & & Risk Ratio (M-H, Fixed, 95\% CI) & Not estimable \\
\hline 1.3 Non-anatomical reduction & 1 & & Risk Ratio (M-H, Fixed, 95\% CI) & Not estimable \\
\hline 2 Functional outcomes & 1 & & Risk Ratio (M-H, Fixed, 95\% CI) & Totals not selected \\
\hline 2.1 Pain & 1 & & Risk Ratio (M-H, Fixed, 95\% CI) & Not estimable \\
\hline $\begin{array}{l}2.2 \text { Limitation in range of } \\
\text { motion }\end{array}$ & 1 & & Risk Ratio (M-H, Fixed, 95\% CI) & Not estimable \\
\hline 3 Complications & 1 & & Risk Ratio (M-H, Fixed, 95\% CI) & Totals not selected \\
\hline 3.1 Deep infection & 1 & & Risk Ratio (M-H, Fixed, 95\% CI) & Not estimable \\
\hline 3.2 Superficial infection & 1 & & Risk Ratio (M-H, Fixed, 95\% CI) & Not estimable \\
\hline 3.3 Compartment syndrome & 1 & & Risk Ratio (M-H, Fixed, 95\% CI) & Not estimable \\
\hline 3.4 Nerve injury & 1 & & Risk Ratio (M-H, Fixed, 95\% CI) & Not estimable \\
\hline $\begin{array}{l}3.5 \text { Refracture on implant } \\
\text { removal }\end{array}$ & 1 & & Risk Ratio (M-H, Fixed, 95\% CI) & Not estimable \\
\hline
\end{tabular}


Analysis I.I. Comparison I Immediate mobilisation versus plaster cast immobilisation, Outcome I Delayed union (at 12 weeks).

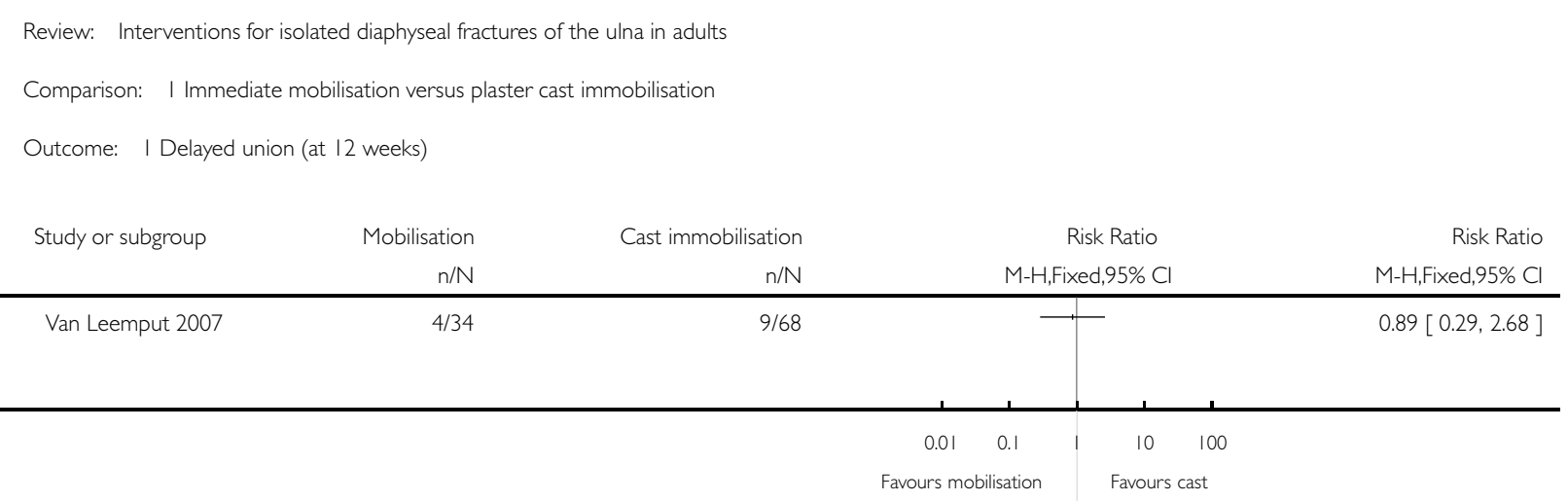

Analysis 2.I. Comparison 2 Short arm plaster cast versus long arm plaster cast immobilisation, Outcome I Delayed union (at 12 weeks).

Review: Interventions for isolated diaphyseal fractures of the ulna in adults

Comparison: 2 Short arm plaster cast versus long arm plaster cast immobilisation

Outcome: I Delayed union (at 12 weeks)

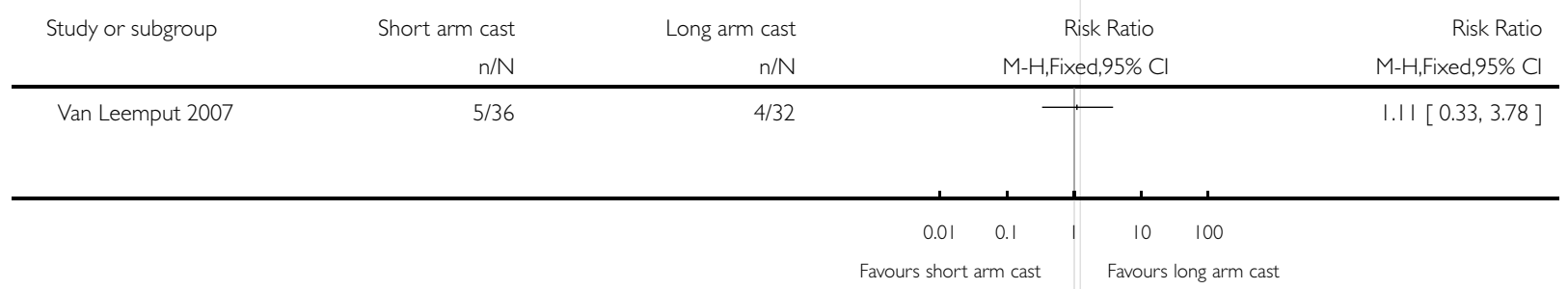


Analysis 3.1. Comparison 3 Point contact fixator (PC-Fix) versus the limited contact dynamic compression plate (LC-DCP), Outcome I Anatomical outcomes.

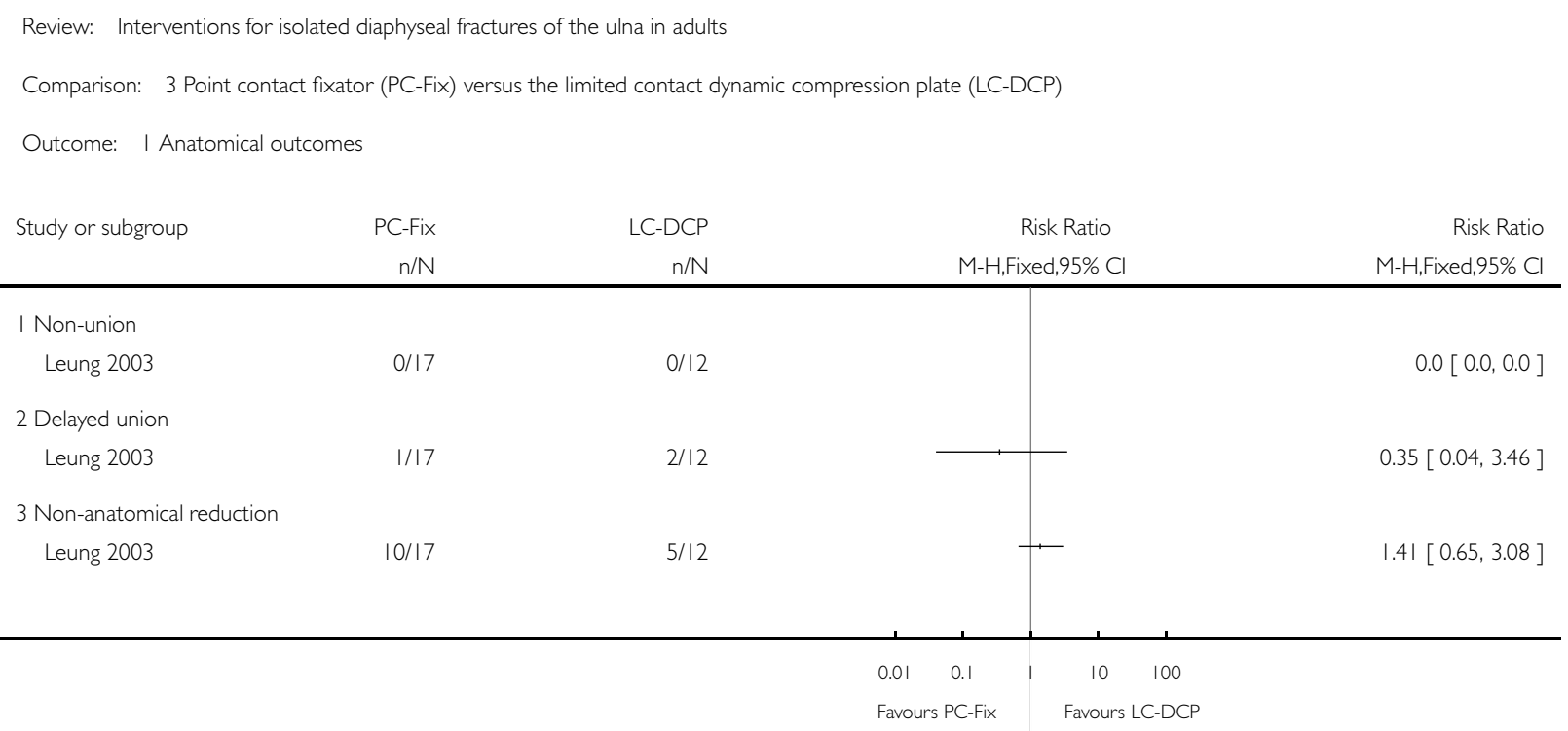

Analysis 3.2. Comparison 3 Point contact fixator (PC-Fix) versus the limited contact dynamic compression plate (LC-DCP), Outcome 2 Functional outcomes.

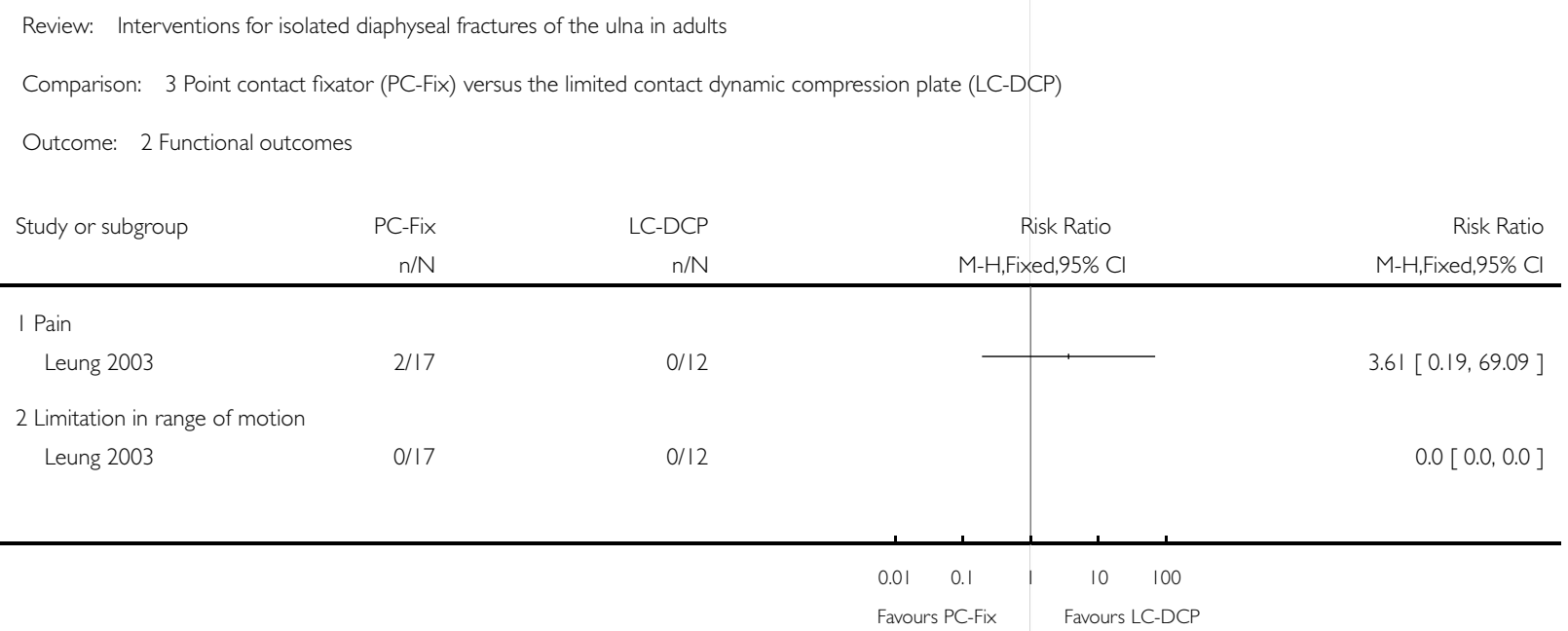


Analysis 3.3. Comparison 3 Point contact fixator (PC-Fix) versus the limited contact dynamic compression plate (LC-DCP), Outcome 3 Complications.

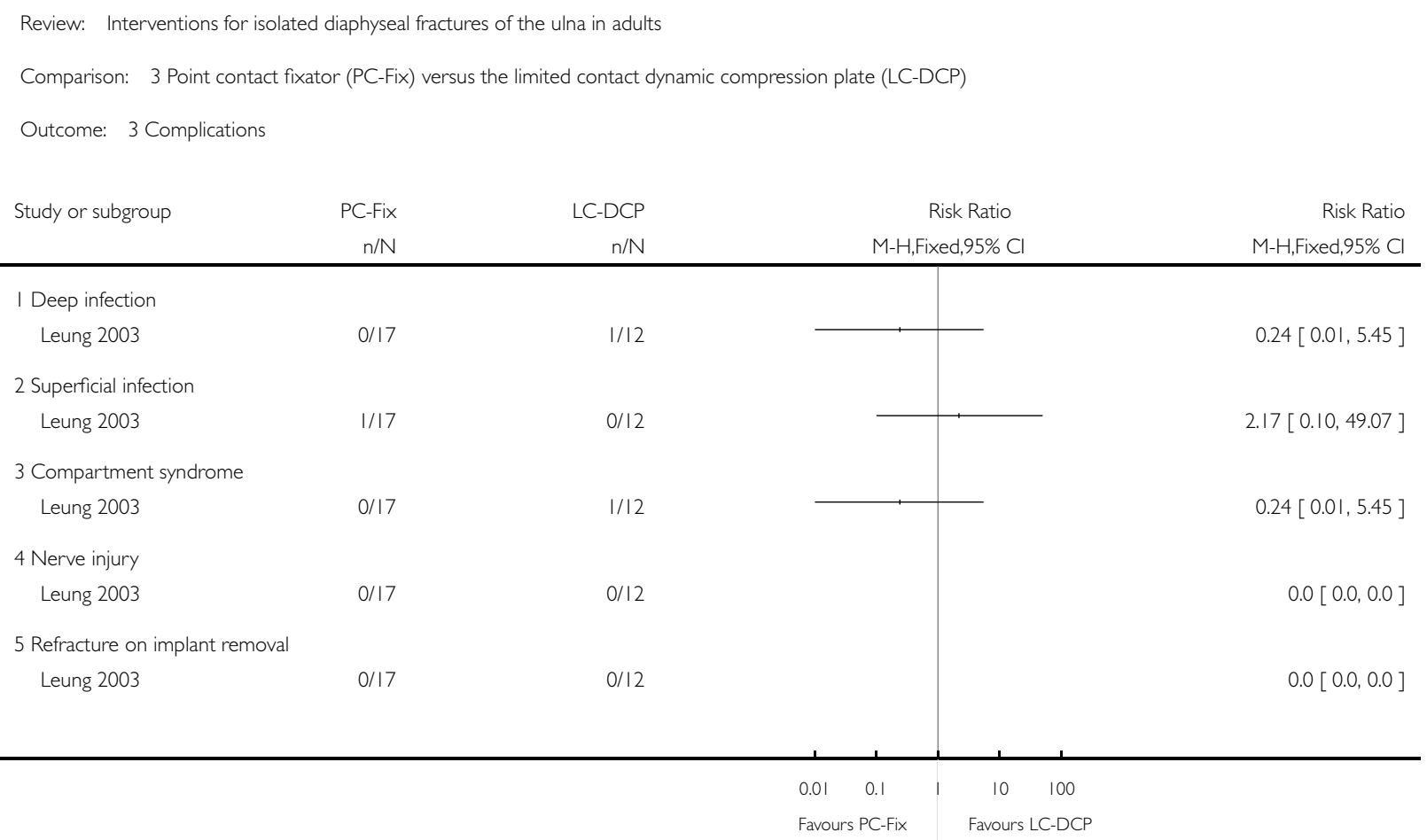

\section{A P P E N D I CES}

\section{Appendix I. Search strategies}

\section{MEDLINE (OVID WEB)}

1. Ulna/

2. (ulna or ulnar).tw.

3. or/1-2

4. Fractures, Compression/or Fractures, Ununited/ or Fractures, Cartilage/or Fractures, Malunited/or Fractures, Spontaneous/or Fractures, Bone/ or Fractures, Open/ or Fractures, Closed/ or Fractures, Stress/ or Fractures, Comminuted/

5. fracture\$.tw.

6. or/ $4-5$

7. and $/ 3,6$

8. Ulna Fractures/

9. or/7-8

10. (shaft or diaphys $\$$ or nightstick).tw.

11. and/9-10

\section{EMBASE (OVID WEB)}

1. Ulna/

2. (ulna or ulnar).tw. 
3. or/1-2

4. Fracture/

5. fracture $\$ . t w$.

6. or/4-5

7. and $/ 3,6$

8. Ulna Fracture/

9. or/7-8

10. (shaft or diaphys $\$$ or nightstick).tw.

11. and/9-10

12. exp Randomized Controlled trial/

13. exp Double Blind Procedure/

14. exp Single Blind Procedure/

15. exp Crossover Procedure/

16. Controlled Study/

17. or/12-16

18. ((clinical or controlled or comparative or placebo or prospective $\$$ or randomi\# $\#$ ed) adj3 (trial or study)).tw.

19. (random $\$$ adj7 (allocat $\$$ or allot $\$$ or assign $\$$ or basis $\$$ or divid $\$$ or order $\$$ )).tw.

20. (( $\operatorname{singl} \$$ or doubl\$ or trebl\$ or tripl\$) adj7 (blind\$ or mask\$)).tw.

21. (cross?over\$ or (cross adj1 over\$)).tw.

22. ( (allocat $\$$ or allot $\$$ or assign $\$$ or divid $\$$ ) adj3 (condition $\$$ or experiment $\$$ or intervention $\$$ or treatment $\$$ or therap $\$$ or control $\$$ or group\$)).tw.

23. or/18-22

24. or $/ 17,23$

25. limit 24 to human

26. and $/ 11,25$

\section{CINAHL (OVID WEB)}

1. Ulna/

2. (ulna or ulnar).tw.

3. or/1-2

4. Fractures/

5. fracture $\$ . t w$.

6. or/4-5

7. and $/ 3,6$

8. Ulna Fractures/

9. or/7-8

10. (shaft or diaphys $\$$ or nightstick).tw.

11. and/9-10

\section{CENTRAL (Wiley InterScience)}

\#1 MeSH descriptor Ulna, this term only

\#2 (ulna or ulnar)

\#3 (\#1 OR \#2)

\#4 MeSH descriptor Fractures, Bone, this term only

\#5 MeSH descriptor Fracture Fixation explode all trees

\#6 MeSH descriptor Fracture Healing, this term only

$\# 7$ (fracture)

\#8 (\#4 OR \#5 OR \#6 OR \#7)

\#9 (\#3 AND \#8)

\#10 MeSH descriptor Ulna Fractures explode all trees \#11 (\#9 OR \#10)

Interventions for isolated diaphyseal fractures of the ulna in adults (Review)

Copyright ( 2009 The Cochrane Collaboration. Published by John Wiley \& Sons, Ltd. 
\#12 (shaft or diaphys\$ or nightstick)

\#13 (\#11 AND \#12)

\section{WHAT'S NEW}

Last assessed as up-to-date: 25 January 2009.

6 May 2009 New search has been performed

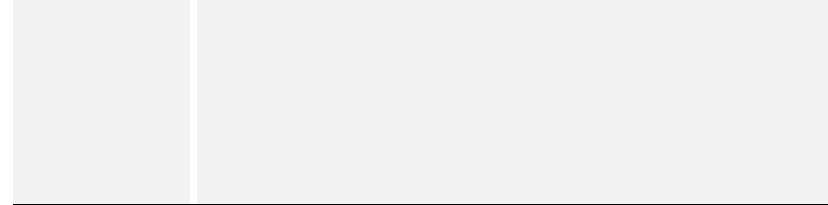

In this issue (Issue 3, 2009) the search for trials was updated to December 2008. One new trial evaluating conservative treatment options was identified and included. Outcomes were grouped into primary and secondary outcomes. Risk of bias was assessed. There were changes to the conclusions of the review.

6 May 2009 New citation required and conclusions have changed

Some changes were made to the conclusions as a result of the addition of evidence from a newly included trial.

\section{H IS T O R Y}

Protocol first published: Issue 4, 1997

Review first published: Issue 3, 1998

\begin{tabular}{l|l|l}
\hline 5 August 2008 & Amended & Converted to new review format. \\
\hline 3 October 2006 & New search has been performed & $\begin{array}{l}\text { In Issue 1, 2007, the search for trials was updated to September 2006. No new } \\
\text { trials or associated data were identified. The 'Synopsis' was amended to a 'Plain } \\
\text { language summary'. The 'Objectives' were reworded but remained as before. } \\
\text { Methodological quality scores of individual criteria were no longer summed. } \\
\text { There was no change to the conclusions of the review. }\end{array}$ \\
\hline For details of all updates, please see 'Published notes'.
\end{tabular}




\section{CONTRIBUTIONS OFAUTHORS}

Paddy Pearce initiated the review and, with Agop Der Tavitian, developed the protocol. Paddy Pearce and Helen Handoll undertook the literature search. All three reviewer authors assessed trial quality and extracted trial data. Paddy Pearce wrote the first draft of the review. Helen Handoll critically rewrote the review and subsequent revisions.

All updates, including updating the literature search, of the review were prepared by Helen Handoll and checked by Paddy Pearce. For the fifth and eight updates, Helen Handoll contacted the trialists of the newly identified/included trial. Both authors assessed trial quality and extracted trial data.

Helen Handoll and Paddy Pearce are the guarantors for the review.

\section{DECLARATIONS OF INTEREST}

None known.

\section{SOURCES OF SUPPORT}

\section{Internal sources}

- University of Teesside, Middlesbrough, UK.

\section{External sources}

- No sources of support supplied

\section{NOTES}

Non substantive changes made (January 2000) for Issue 2, 2000.

(1) Literature search extended to August 1999.

(2) Synopsis added.

(3) One more excluded study.

(4) Scores for individual items of the methodological quality assessment scheme changed from 3,2,1 to 2,1,0.

Non substantive changes made (December 2000) for Issue 2, 2001.

(1) Literature search extended to December 2000.

(2) One more excluded study.

(3) Active follow-up rated in methodological quality.

(4) Relative risks presented instead of Peto odds ratios.

(5) Some comments made on a recently published systematic review.

Non substantive changes made (November 2001) for Issue 2, 2002.

(1) Literature search extended to November 2001.

(2) Some epidemiological information was added.

Non substantive changes made (November 2002) for Issue 2, 2003.

Interventions for isolated diaphyseal fractures of the ulna in adults (Review)

Copyright ( 2009 The Cochrane Collaboration. Published by John Wiley \& Sons, Ltd. 
(1) Literature search extended to November 2003.

(2) Three more excluded studies.

Substantive changes made (January 2004) for Issue 2, 2004

(1) Literature search extended to December 2003.

(2) Addition of new included surgical trial evaluating two types of plates.

Non substantive changes made (January 2005) for Issue 2, 2005.

(1) Literature search extended to January 2005.

(2) Correspondence on one trial added and some other changes made to conform to Cochrane Style Guide.

Non substantive changes made (October 2006) for Issue 1, 2007

(1) Literature search extended to September 2006.

(2) Synopsis modified to a Plain language summary.

(3) Objectives were reworded.

(4) Overall methodological quality scores removed.

Substantive changes made (January 2009) for Issue 3, 2009

(1) Literature search extended to December 2008.

(2) Addition of new included conservative treatment trial.

(3) Restructuring of outcomes into primary and secondary outcomes

(4) Risk of bias implemented.

\section{INDEX TERMS}

\section{Medical Subject Headings (MeSH)}

Diaphyses [injuries]; Fracture Fixation [ ${ }^{*}$ methods]; Randomized Controlled Trials as Topic; Ulna Fractures [*therapy]

\section{MeSH check words}

Adult; Female; Humans; Male 